\title{
Cytology, biochemistry and molecular changes during coffee fruit development
}

\author{
Renato D. De Castro ${ }^{1}$ and Pierre Marraccini2,3*
}

${ }^{1}$ UCSAL (Universidade Católica do Salvador), Laboratório de Estudos em Meio Ambiente - LEMA, Av. Prof. Pinto de Aguiar 2589, Pituaçu, 41740-090, Salvador, BA, Brazil; ${ }^{2}$ CIRAD-Centre de Coopération Internationale en Recherche Agronomique pour le Développement-CP, UMR PIA 1096, TA 80/03, Avenue d'Agropolis, 34398 Montpellier Cedex 5, France ; ${ }^{3}$ IAPAR-Instituto Agronômico do Paraná, LBI-AMG, CP 481, 86001-970, Londrina, PR, Brazil.*Corresponding author: marraccini@cirad.fr

In commercial coffee species (Coffea arabica and Coffea canephora), fruit development is a lengthy process, characterized by tissue changes and evolutions. For example, soon after fecundation and up to mid development, the fruit is mainly constituted of the pericarp and perisperm tissue. Thereafter, the perisperm gradually disappears and is progressively replaced by the endosperm (true seed). Initially present in a "liquid" state, the endosperm hardens as it ripens during the maturation phase, as a result of accumulation of storage proteins, sucrose and complex polysaccharides representing the main reserves of the seed. The last step of maturation is characterized by the dehydration of the endosperm and the color change of the pericarp. Important quantitative and qualitative changes accompany fruit growth, highlighting the importance of its study to better understand the final characteristics of coffee beans. Following a description of the coffee fruit tissues, this review presents some data concerning biochemical, enzymatic and gene expression variations observed during the coffee fruit development. The latter will also be analyzed in the light of recent data (electronic expression profiles) arising from the Brazilian Coffee Genome Project. Key words: Coffea spp, bean development, cell cycle, endosperm, EST, gene expression, pericarp, perisperm.

Cytology, biochemistry and molecular changes during coffee fruit development: Em espécies comerciais de café (Coffea arabica e Coffea canephora), o desenvolvimento do fruto de café é um processo longo, caracterizado por mudanças e evoluções nos tecidos. Por exemplo, logo após a fecundação e até a metade do desenvolvimento, o fruto é principalmente constituído pelo pericarpo e perisperma. Em seguida, o perisperma gradualmente desaparece e é progressivamente substituído pelo endosperma (semente verdadeira). Inicialmente o endosperma apresenta-se no estado "líquido", o endosperma endurece durante a fase de maturação, como resultado do acúmulo gradual de proteínas de reserva, sacarose e polissacarídeos complexos representando as principais reservas da semente. O último passo da maturação é caracterizado pela desidratação do endosperma e pela mudança de cor do pericarpo. Importantes alterações quantitativas e qualitativas acompanham o crescimento do fruto, ilustrando a importância do seu estudo para melhor compreender as características finais das sementes de café. Seguindo a descrição dos tecidos do fruto de café, esta revisão apresenta alguns dados relativos às variações bioquímicas, enzimáticas e de expressão gênica durante o desenvolvimento do fruto. A expressão de genes será também analisada em função de dados recentes (perfil de expressão eletrônica) oriundos do Projeto Genoma Brasileiro Café.

Palavras-chave: Coffea spp, ciclo celular, desenvolvimento da semente, endosperma, EST, expressão gênica, pericarpo, perisperma.

\section{INTRODUCTION}

The Coffea genus contains around 100 species (Charrier and Berthaud, 1985). Within these species, $C$. arabica (Arabica) and C. canephora (Robusta) represent respectively about $70 \%$ and $30 \%$ of the coffee market
(Marshall, 1985). In both cases, coffee fruits are classified as "drupes", characterizing a pulpy mesocarp with lignified endocarp (figure 1). At the genetic level, Arabica is tetraploid ( $2 \mathrm{n}=4 \mathrm{x}=44$ chromosomes), originating from a natural cross between $C$. canephora and C. eugenoides (Lashermes et 
al., 1999, 2000). It is a self-pollinating species. This in part explains its reduced genetic diversity and also the difficulty in incorporating traits of interest (Charrier and Berthaud, 1985). On the other hand, Robusta coffee is diploid $(2 n=22$ chromosomes) and highly self-incompatible, due to the presence of a gametophytic system of incompatibility controlled by one gene with multiple S-alleles (Berthaud, 1980). This explains the higher genetic diversity within this species and also permits its genetic improvement by conventional breeding techniques (Montagnon, 2000).

At the beverage quality level, coffee from beans of $C$. arabica is preferred by consumers mainly in view of its lower bitterness and better flavor (see: Genetics of coffee quality, Leroy et al. in this issue). It is now well known that some compounds that accumulate in mature coffee beans play an important role in the quality of the beverage. For example, sucrose, which ranges from $6 \%$ to $8.5 \%$ in Arabica and from 0.9 to $4.9 \%$ in Robusta (Clifford, 1985a; Campa et al., 2004), is considered as one the major contributors to coffee cup quality because its degradation during roasting leads to a wide range of compounds (i.e. aliphatic acids) involved in coffee flavor, either as the volatile aroma compounds, or as non-volatile taste compounds (De Maria et al., 1996; Tressl et al., 1998; Ginz et al., 2000). In contrast, caffeine and chlorogenic acids (CGA) are found at higher levels in Robusta than in Arabica, and are responsible for beverage bitterness (Leloup et al., 1995). Due to the importance of caffeine in human health (Bättig, 1985; Schilter et al., 2001), caffeine metabolism has been studied for some time in coffee (see: Metabolism of alkaloids, Ashihara et al. in this issue). Many genes implicated in its biosynthesis were recently cloned (Moisyadi et al., 1998, 1999; Ogawa et al., 2001; Mizuno et al., 2003a, 2003b; Uefuji et al., 2003) and the

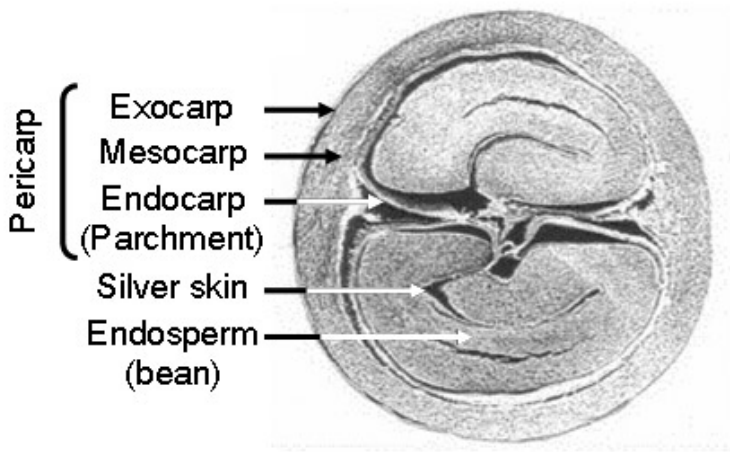

Figure 1. Schematic representation of the tissues present at the mature stage (220-250 DAF) of fruits of Coffea sp. (courtesy of Nestlé Inc.). first trials to produce transgenic coffee plants with reduced caffeine content in beans are being carried out (Ogita et al., 2003, 2004).

Except for the large number of studies concerning caffeine metabolism in coffee, little data are available concerning genes, enzymes and metabolic pathways of many other biochemical compounds also important for coffee cup quality (ex. sucrose metabolism) or for human health (ex. diterpenes). Considering that the knowledge of coffee cytology, biochemistry and molecular biology events is essential for an integrated view of coffee seed physiology, the main objective of this article is to review cellular and tissue differentiation, metabolism and gene expression. Each of these subjects is described below in separated sections.

\section{Coffee fruit development: tissue evolution and changes}

In the genus Coffea, the fruit development covering the time between anthesis and full ripening is variable from few (10 to 12) weeks, as in C. racemosa and pseudozanguebariae, to more than a year for $C$. liberica. For the species of high economic value, $C$. arabica requires 6 to 8 months to mature while $C$. canephora requires 9 to 11 months (for a review, see Cannell 1985). Fruit growth is asynchronous during development, with different proportions of various fruits sizes on the same plant. Although possibly related to the several flowering events that may occur in C. arabica during each production season, a tendency for synchrony was observed during the later stages of maturation when a significantly higher proportion of fruits entered the largest sized ripe 'cherry' stage (De Castro et al., 2005). Despite the asynchrony in fruit growth and differences in the length of the reproductive cycle between coffee species, key steps of fruit and seed development appear to be identical, at least between the commercial species.

In $C$. arabica var. Bourbon, for which a detailed study of tissue evolution was reported, a rapid growth of fruits was observed between 0 and 7 WAF (weeks after flowering), reaching its maximum final size at 17 WAF (Wormer, 1966). The initial growth coincided with the sudden development of the perisperm up to 11-12 WAF, at the time when the endosperm had also begun to be identified. Thereafter, the endosperm continued to grow gradually, until completely occupying the space (locule) left by the inner portion of the perisperm at around $19 \mathrm{WAF}$, as observed for $C$. arabica var. Acaiá Cerrado (figure 2). At the maturity stage of the coffee fruits, usually occurring around 30 to $35 \mathrm{WAF}$, only the outer layer of the perisperm tissue remains surrounding 

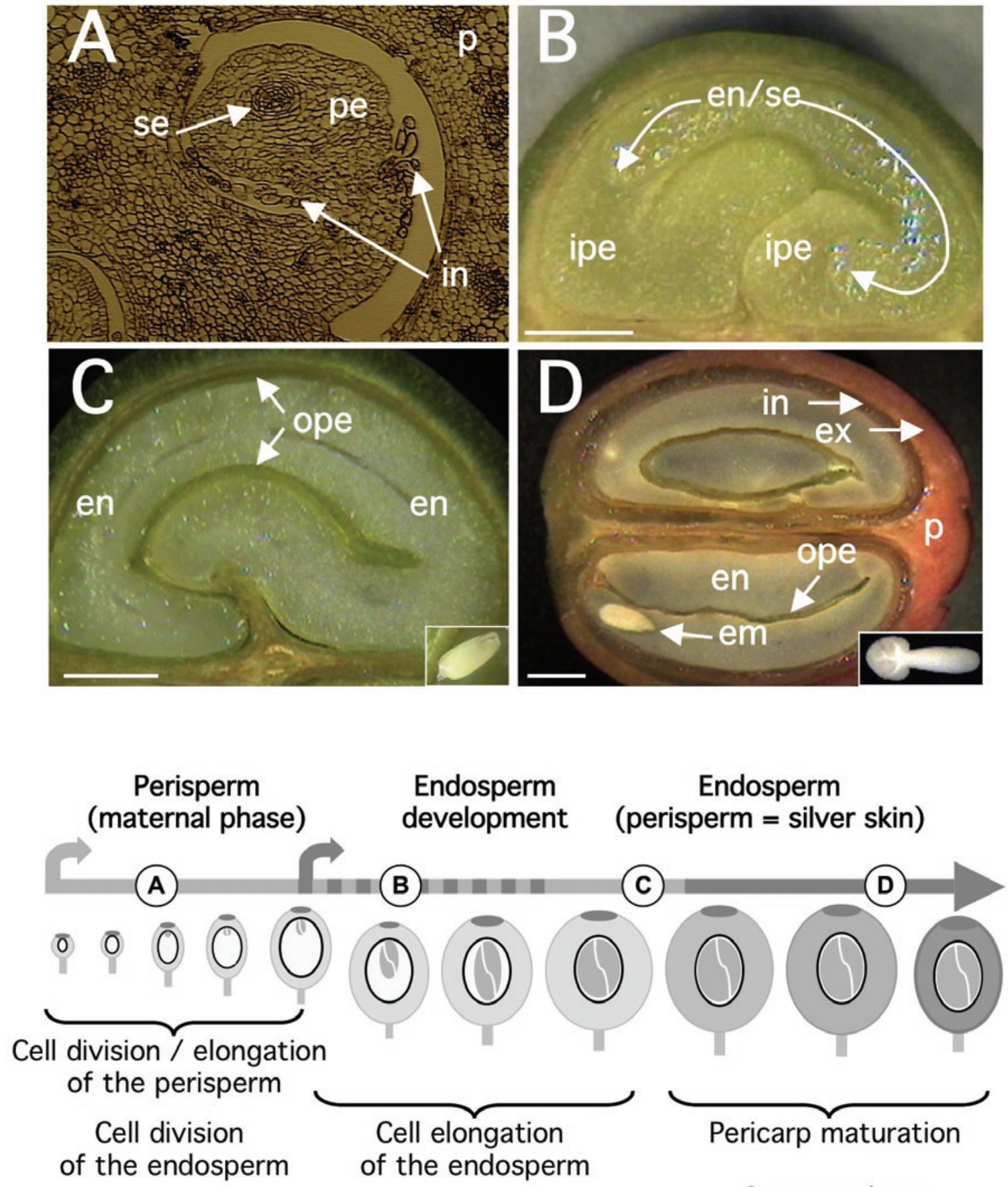
of the endosperm of the endosperm

Storage phase

Figure 2. Key steps of coffee fruit development. Coffee fruits of C. arabica var. Acaiá Cerrado MG-1474 were harvested on different days after flowering (DAF) and sectioned for analysis (Estanislau, 2002). A: ovary after anthesis (0-60 DAF showing the growing perisperm (pe) tissue, the integuments (in) and the young embryo sac (se) that will further develop into the endosperm (en). Cell layers of the future pericarp (p) are also indicated (x 60). B: transversal section of immature fruit at 90 DAF showing the pericarp (p) and the liquid endosperm tissue (en), also referred to as the "true seed" (se), which grows (arrows) absorbing the inner perisperm tissue (ipe). C: transversal section of immature fruit between 120-150 DAF showing the remaining folded outer perisperm layer (ope) enclosing the completely milky endosperm. D: longitudinal section of mature cherry fruits at $230-240$ DAF showing the two developed mature seeds enclosing one cotyledonary mature embryo (em) inside the solid endosperm or isolated (right corner). Internal (in) and external (ex) parts of the mesocarp are also indicated. Bars from B to D represent 2 mm. Below, is presented a schematic graph of tissue changes occurring during coffee fruit development. 
the endosperm (figures 1and 2), sometimes referred to as the "silver skin" (Mendes, 1941, 1942; Wormer, 1964, 1966; De Castro et al., 2001, 2005; Miriam et al., in this issue). The endosperm actually corresponds to the bean that, after the post-harvest treatments, will form the "green coffee" that is sold in the international markets.

Previous studies have reported detailed information on the histology and cytology of developing coffee beans by light and transmission electron microscopy coupled with specific staining (Dentan, 1985a, 1985b). From the biochemical point of view, exchanges of sugars and organic acids between the perisperm and endosperm tissues were also shown to occur (Rogers et al., 1999b; Marraccini et al., 2001a). In addition, the thin perisperm layer (future silver skin), which is not consumed by the growing endosperm, remains as a greenish tissue, suggesting it could play important functions during seed filling, for example in the translocation of assimilates to the developing endosperm (De Castro et al., 2005). To better appreciate changes occurring during coffee fruit development, a rapid description of coffee fruit tissues and cell cycle events is given below.

Pericarp: The pericarp is composed of several tissues (Avallone 1999): the exocarp (peel), the mesocarp and the endocarp (figure 1). The exocarp persists as a green color colored tissue during most of the coffee fruit development, becoming transiently yellow and then red at the final stage of development. The change in color is due to the disappearance of chlorophyll pigments and anthocyan anthocyan accumulation during the last stages of fruit maturation (Marín-López et al., 2003). In some natural mutants of C. arabica, also referred to as yellowish ("Amarelo") cultivars, the exocarp does not become red, but apparently remains yellow at the mature stage (Carvalho et al., 1957). Whatever the species considered, the change in color is of great importance since it is the main criterion for fruit maturation, even if the absence of coupling between the maturation of pericarp and endosperm (bean) has also been observed (Guyot et al., 1988).

The mesocarp, also commonly referred to as the "true pulp", is rich in sugar (both reducing sugars and sucrose) and water. With $0.5-2 \mathrm{~mm}$ thickness, it can be divided into the external and internal parts (figure 2D). The former is formed of parenchyma cells with compact and dense cell walls in green fruits that become thinner during maturation, probably due to pectin modifications (Ouguerram, 1999). However, the cytological structure of the internal mesocarp, also referred to as the mucilaginous tissue in mature fruits, is still controversial (Beille, 1947; Menezes and Maneiro, 1955).
In the most internal location, the endocarp (also called parchment layer or "pergaminho") is a hard and lignified tissue of around $150 \mu \mathrm{m}$ (Mendes, 1942), and was proposed to protect the coffee seed against digesting enzymes from the gut of frugivorous animals (Urbaneja et al., 1996).

The first data on pericarp growth and development in Arabica were reported by Keller et al. (1971, 1972). Dry weight measured regularly during pericarp development exhibited a biphasic time course, what was also observed when measuring fresh weight (figure 4). Such a process was also seen in Robusta, but with a delay due to the increased maturation time usually observed for this species.

In immature green coffee berries, the exocarp is a photosynthetically active tissue and could contribute to supply the needs of carbohydrates especially during the bean-filling stage (Vaast et al., 2006). Measurements of chlorophyll, carotenoids and anthocyan contents during pericarp maturation were followed in C. arabica L. var. Colombia (MarínLópez et al., 2003). A great decrease in chlorophyll content was observed between 182 (16 $\mu \mathrm{g}^{\mathrm{g}} \mathrm{g}^{-1}$ dry weight, DW) and $203\left(7 \mu \mathrm{g} \mathrm{g}^{-1} \mathrm{DW}\right)$ days after flowering (DAF), followed by a rapid and sudden anthocyan accumulation between 210 and 224 DAF, from 1.5 to $47 \mu \mathrm{g} . \mathrm{g}^{-1} \mathrm{DW}$.

Kumar and Tieszen (1976) estimated that green coffee berries could provide $100 \%$ of their maintenance requirements and up to $30 \%$ of their growth requirements through their own photosynthetic activity. In a more recent study, it was estimated that berries could produce about $30 \%$ of their own daily respiration costs and contributed to approximately $12 \%$ of their total carbon requirements (Vaast et al., 2005). Therefore, even if large long distance carbohydrate transfers occur in coffee trees (Cannell, 1971), the contribution of the pericarp to the coffee bean development is far from negligible.

Perisperm: The coffee perisperm, which has also been in the past referred to as the "integument" or "spermoderm", develops from the nucellus of the ovule soon after the fecundation (Mendes, 1942). Its persistence up to the mature stage was still a matter of debate since several articles reported the mature coffee bean as being composed of perisperm (Dentan, 1985a; West et al., 1995) as initially reported by Houk $(1936,1938)$.

Other studies identified the perisperm as the tissue that initially develops soon after the fecundation up to the occupation of the entire volume of the locule (Winton and Winton, 1939; Vishveshwara and Chinnappa, 1965; Wormer, 
1966). Intense cell divisions and expansion occurring during early stages of perisperm development (0-90 DAF, figure 6A) are characterized by the sudden increase of its fresh weight (figure 4). In further developmental stages (90-150 DAF), the perisperm can be identified as the inner perisperm (ipe), with large cells localized close to the endosperm, and the outer perisperm (ope), formed by smaller cells (figure 5). A growing cuticle cell layer (cc) is also observed between the endosperm and the inner perisperm, and is composed of walls of the inner perisperm cells that gradually disappear as the endosperm grows. From 150 DAF to 200 DAF, the remaining outer perisperm looks like a thin green testa entirely surrounding the endosperm (figures 2C-D). At the mature stage, the perisperm appears as a thin pellicle of about $70 \mu \mathrm{m}$ thick silver skin, and has been characterized as being formed by sclerenchyma cells organized longitudinally, probably arising from absorbed perisperm cells (Dedecca, 1957), a phenomenon often observed in dried coffee berries or beans as a result of dehydration (De Castro et al., 2001, 2005).

Because of the sporophytic origin of the perisperm, it has been proposed that the maternal genome could be in part responsible of some physical final characteristics of the coffee beans, like the final size of the coffee bean for example (Vishveshwara and Chinnappa, 1965; Rogers et al., 1999b). Recent experiments analyzing enzymatic activities and gene expression in this tissue, clearly suggest the participation of the perisperm in such a way, at least during the time when it is easily separated from the endosperm (Geromel et al., submitted). However, to our knowledge, no maternal effects on this character have been observed in either Arabica (B. Bertrand, personal communication) or Robusta breeding projects (T. Leroy and C. Montagnon, personal communication).

Endosperm: As in other plants, the endosperm of coffee is a triploid tissue with a non-sporophytic origin (Mendes, 1941, Medina, 1964, 1965, De Castro et al., 2001). Cytological observations carried out a few days after anthesis already allows its identification, as the embryo sac (se) (figure 2A). However, it can be easily identified and separated from the perisperm because of its milky color (figure 2B) only after 90 DAF. Up to this stage, endosperm cells are characterized by thin cell walls that then begin to thicken between 130190 DAF (figure 5B-C), due to the deposition of complex polysaccharides like arabinogalactans and galactomannans (Dentan, 1985b). This period also corresponds to the "storage phase", when intense gene expression is also observed (see section "Gene expression during coffee fruit development").

At the mature stage (around $230 \mathrm{DAF}$ ), the endosperm contains polyhedric cells that could be isodiametrically divided into hard external endosperm, with cells of a polygonal shape, and a soft internal endosperm with rectangular cells (figure 5D). Walls of both cell types are crossed by plasmodesmata that should permit exchange of solute compounds between cells (De Melo Ayres, 1954; Dentan, 1985a, 1985b). It is also a hard tissue, due to the high polysaccharide deposition in the cell walls (Wolfrom et al., 1961; Wolfrom and Patin, 1964). The main polysaccharide is a $\beta$-(1 $1 \rightarrow 4)$-D-mannan which is poorly soluble due to its low degree of galactose branchings (Redgwell et al., 2003). As a storage tissue, the mature endosperm accumulates compounds that will serve as nutrient reserves that are mobilized by the embryo during the germinative process of the coffee bean (seed), such as 11S legumin-type storage proteins, which represent around half of soluble proteins (see section "Gene expression during coffee fruit developmentgenes coding for storage proteins").

Cell cycle: The analysis of cell cycle events serves as a good means for characterizing the phases of histo-differentiation and organogenesis during seed development (De Castro, 1998; Jing et al., 1999). The spatial and temporal profiles of tubulin accumulation correspond to different configurations of microtubular cytoskeleton as cells progress through division or expansion events (figure 6). In developing $C$. arabica seeds, a sequential pattern of decreasing tubulin accumulation has been observed, first in perisperm cells, then in endosperm and finally in embryos, until undetectable levels are attained in each tissue at the final stages of maturation (Estanislau, 2002; De Castro et al., 2005).

High contents of tubulin were observed during organogenesis of the coffee perisperm until it turned into the thin dehydrated silver skin layer. The initial high tubulin content corresponded to an abundant network of cortical and mitotic microtubular cytoskeleton configurations in fruits up to 8 $\mathrm{mm}$ diameter at $90 \mathrm{DAF}$, just prior to the moment when the growth of endosperm was first detected (figure 6A). From 90 up to $150 \mathrm{DAF}$, the coffee fruits then grew as result of perisperm cell enlargement, simultaneously with the histo-differentiation and growth of the endosperm and embryo, when intense mitotic and expansion activities could be observed (figure 6A-C). During this period, growth was made possible through the simultaneous consumption of the inner portion 
of the perisperm, yielding space for the growth of endosperm (figure 6C), with the seed attaining its final size at around 150 DAF. From 150 DAF onwards, organogenesis was resumed towards the completion of maturation $(\approx 255 \mathrm{DAF}$ in the case of C. arabica var. Acaiá Cerrado exemplified here), and was characterized by the complete degradation of the microtubular network and the decrease in tubulin content in all tissues at the final maturation stages (figure 6C-E).

Overall, histo-differentiation is characterized by high contents of tubulin, and intense mitotic and cortical microtubular cytoskeletons, that are respectively related to cell division and expansion. On the other hand, organogenesis is the result of only cell expansion events, which occur concomitantly with the degradation of cortical microtubules and tubulin contents once maturation is complete (De Castro, 1998; Jing et al., 1999; De Castro et al., 2000, 2005). The patterns of microtubules and tubulin degradation in endosperm and embryos during coffee seed maturation are similar to those detected during the development of other seeds species such as neem (Azadirachta indicat Juss.), tomato (Lycopersicon esculentum Mill) and cucumber (Cucumis sativum) (Sacandé et al., 1997; De Castro, 1998; De Castro and Hilhorst, 2000; Jing et al., 2000; Sacandé, 2000).

Conclusions: The understanding of coffee bean cytology, tissue evolution and relationships between pericarp and endosperm, are essential to clarify the key steps of coffee fruit development and metabolism. For example, studies performed by incubating leaves of branches bearing coffee fruits at approximately 120 DAF with ${ }^{14} \mathrm{CO}_{2}$, clearly showed that the radioactivity was rapidly converted, via photosynthesis, to photoassimilates (presumably mainly sucrose), and that these photoassimilates were actively unloaded into fruit tissues, with most of ${ }^{14} \mathrm{C}$ accumulating in the perisperm (Geromel et al., 2005). When fruits at 120 DAF were feed with ${ }^{14} \mathrm{C}$-sucrose by applying sucrose solution in a pericarp section, the radioactivity was observed not only in this tissue but also in the endosperm, showing the existence of active transport of sugars between these two tissues (Geromel et al., submitted), as reported previously for caffeine (Baumann and Wanner, 1972). These data also indicate that the endocarp should function as a physical barrier, thereby limiting the diffusion of biochemical compounds between the pericarp and other tissues. In that case, biochemical compounds (i.e. sugars, caffeine) should be transported from source tissues (i.e. leaves and pericarp) initially to the perisperm, where they should accumulate transiently, before being further downloaded to the endosperm.

Cytological observations have effectively reported the existence of narrow contacts between the perisperm and endosperm tissues, which should facilitate exchanges between these tissues, either by passive diffusion of by active transport that could require specific-transporters. The existence of intense transfer between the perisperm and endosperm should also explain why starch was strongly detected in the outer perisperm but undetectable in inner perisperm cells localized close to the endosperm (Geromel et al., submitted). Large exchanges and diffusion of metabolites are also supposed to occur in the parenchymatous cells of the endosperm and could be facilitated by the presence of plasmodesmata (De Melo Ayres, 1954; Dentan, 1985a). This should help the migration of diterpenes, phenolic compounds and serotonine (5-hydroxytryptamine) from the internal endosperm to its epiderm, as has been reported for the last stages of bean maturation (Dentan, 1985b).

\section{Biochemical and enzymatic changes during coffee fruit development}

Several publications describing the levels of the major components in mature coffee grains are available in the literature (Poisson, 1977; Clifford, 1985a). Due to their impact on coffee cup quality, special attention has been dedicated to study transport and accumulation of chlorogenic acids, caffeine and trigonelline in coffee beans (Clifford, 1985b; Mazzafera, 1991; Leloup et al., 1995; Ashihara and Crozier, 2001; Zheng et al., 2004). It is also well documented that environmental factors and agricultural management modify the physiology of coffee fruit development. For example, longer maturation times and increased bean sizes are usually observed for plants grown at high altitude or in shade conditions (Muschler, 2001; Guyot et al., 1996; Vaast et al., 2006). In some cases, subtle modifications of the biochemical composition of the green coffee bean were observed and suggested to explain the better quality of coffee produced in those conditions. For example, higher sucrose content was proposed to be responsible for the better beverage quality of $C$. arabica var. Catuaí cultivated at high altitude (Guyot et al., 1996). More recently, slight increases of fat content were observed in beans of coffee plants grown under shade (Vaast et al., 2006) or at higher altitude (Decazy et al., 2003). However, we still do not know which lipid classes are subject to variation under these environmental conditions. 


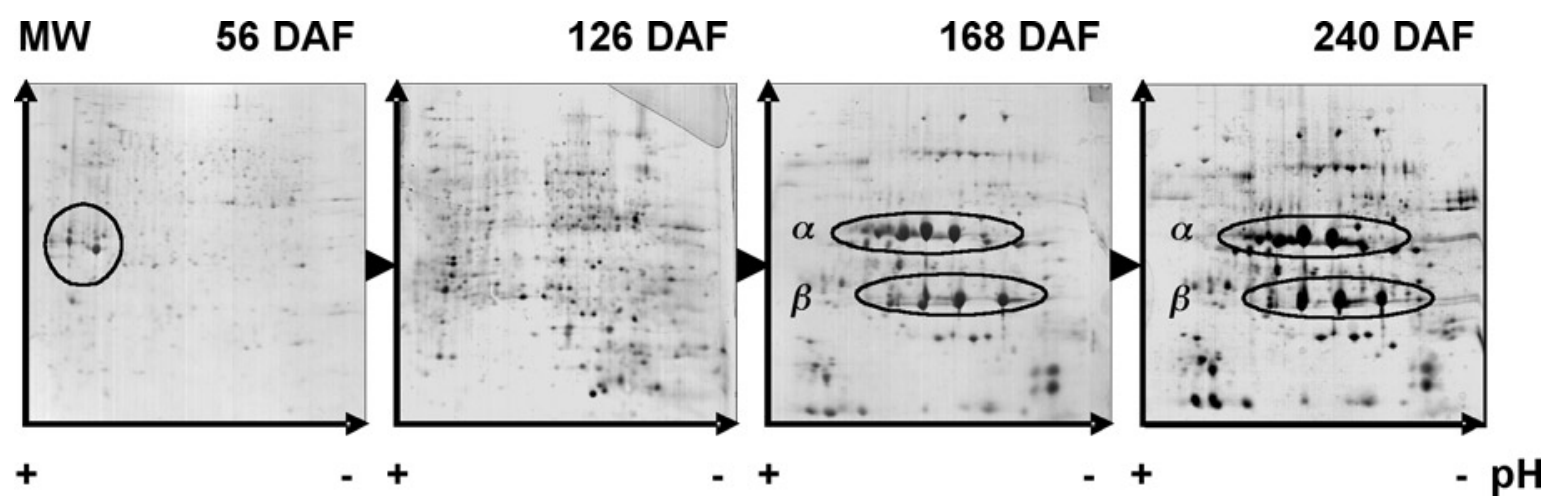

Figure 3. Evolution of proteins during coffee bean development. Soluble proteins of C. arabica var. Caturra T2308 were extracted from beans (perisperm plus endosperm) at different developmental stages, separated by 2-D gel electrophoresis (pI 3-10 linear) and analyzed after silver-stained (Marraccini et al., 2001a). Chitinases of class III (30 kDa, pI [4-5]) are identified (circle) in the perisperm at $56 \mathrm{DAF}$. Subunits $(\alpha: 32 \mathrm{kDa}$ and $\beta: 20 \mathrm{kDa})$ of $11 \mathrm{~S}$ proteins detected in the endosperm during the storage phase (168 DAF) are maintained up to the mature stage (240 DAF) Data from Marraccini et al., (2001a).

Therefore, the understanding of metabolic pathways occurring in coffee bean, as well as at the whole plant level, is of great interest particularly in the search of "candidate" genes linked to quality traits in coffee. Some examples of protein evolution and biochemical pathways during coffee fruit development are given below.

Evolution of proteins during coffee fruit development: Although limited, some studies have been made regarding protein evolution during the development of perisperm and endosperm tissues (Marraccini et al., 2001a; Estanislau, 2002). By 2-D gel electrophoresis, it was shown that perisperm tissue contains several abundant proteins that differ from those accumulated in the endosperm (figure 3). For example, $\mathrm{N}$-terminal and internal sequencing of acidic proteins of homologous MW $(\approx 30 \mathrm{kDa})$ accumulating in the perisperm revealed that they correspond to class-III chitinases (Rogers and Marraccini, unpublished observations) homologous ( $62 \%$ of identity, $78 \%$ of homology) to the partial protein (123 amino acid residues) coded by the $A R-52$ partial cDNA (Rojas-Herrera and Loyola-Vargas, 2002). These proteins are known as PR- (Pathogenesis-Related) proteins that are usually expressed after plant tissue infection (Graham and Sticklen, 1994), but could also play the function of storage proteins, as suggested for the P31 class-III chitinase from Musa acuminata (Clendennen et al., 1998; Peumans et al., 2002). In C. arabica, the expression of AR-52 appear to be up-regulated in tissues with significant cellular division activity, such as during the induction of somatic embryogenesis from foliar explants (Rojas-Herrera and Loyola-Vargas, 2002), suggesting its participation in plant growth and developmental processes, as also proposed for carrot embryos (De Jong et al.,

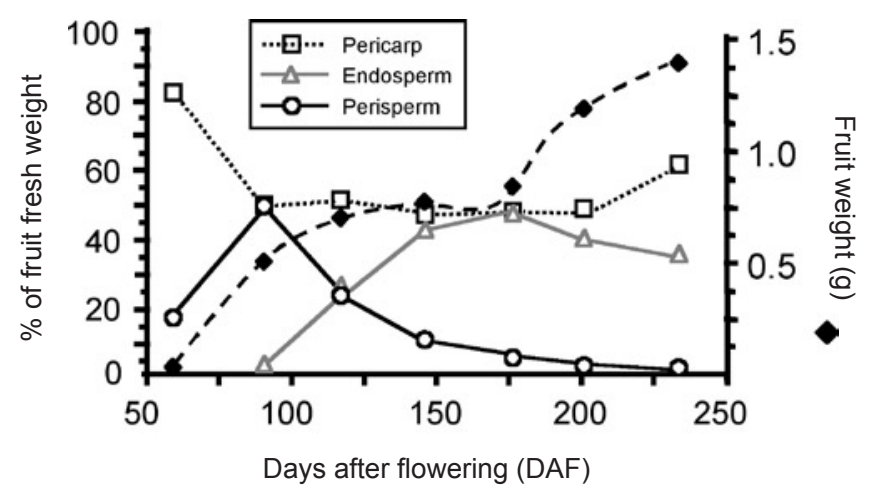

Figure 4. Fresh weight evolution of separated tissues (pericarp, endosperm and perisperm) during fruit development of C. arabica var. Iapar 59. A) Curve of fruit fresh weight (expressed in g, $\square$ ). B) Evolution of pericarp ( $\square)$, perisperm $(O)$ and endosperm $(\triangle)$ expressed in percentage of total fruit fresh weight (FW) (data from Geromel et al., submitted).

1992) and cucumber (Lawton et al., 1994). More recently, the cleaving activity of chitinases on arabinogalactan proteins (AGPs), leading to the release of Nod factor-like molecules, was also reported to promote plant cell division (Schultze and Kondorosi, 1996; Gough, 2003).

Interestingly, the large accumulation of chitinases in young perisperm also coincides with the detection of high amounts of $\beta$-tubulin which, as a component of microtubules, is considered as marker protein indicative of cell division and expansion events (De Castro, 1998; Estanislau, 2002). Indeed, the immunocytochemical detection of mitotic and cortical microtubules confirmed high cellular division and elongation activity in the developing perisperm of C. arabica L. var. Acaiá Cerrado (figure 6). 


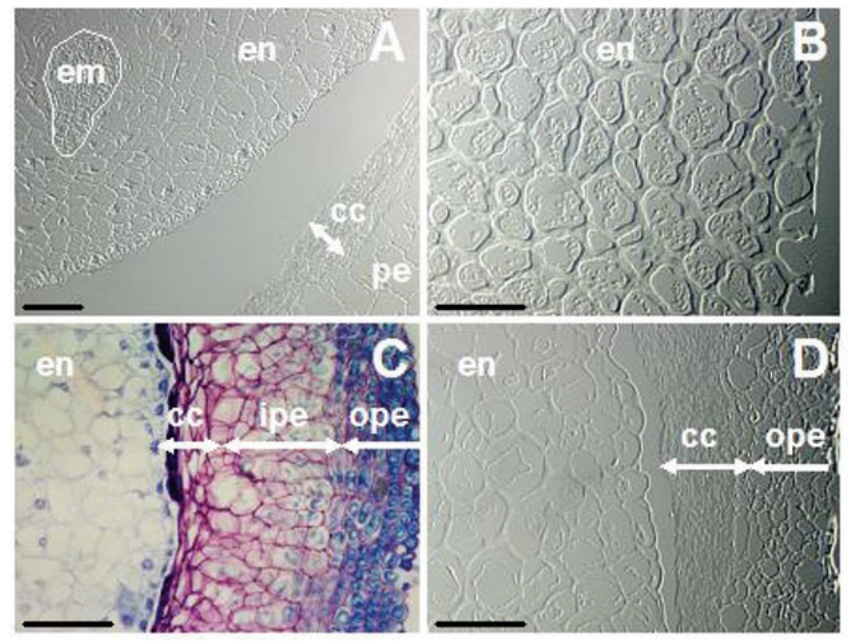

Figure 5. Histological studies of coffee (C. arabica) tissues at different developmental stages. Endosperm (en), cuticle cell layer (cc), embryo (em) and perisperm (pe) divided in outer (ope) and inner (ipe) layers. Materials were sampled at $90 \mathrm{DAF}(\mathrm{A}), 130 \mathrm{DAF}(\mathrm{B}), 150 \mathrm{DAF}(\mathrm{C})$ and mature stage at 230 DAF (D). A, B and D: materials were fixed, embedded in butylmethylmetacrylate, sectioned, fixed on slides according to Baskin et al. (1992) and visualized using Differential Interference Contrast (DIC) microscopy; C: the material was treated and stained with toluidine blue $(0.05 \%)$ according to Gerrits and Smid (1983). The torpedo embryo in A was underlined to facilitate identification. Scale in left corner of each document represents $100 \mu \mathrm{m}$.

When $\beta$-tubulins were detected by Western-blot experiments in the endosperm, their amount decreased gradually from 120 to $210 \mathrm{DAF}$, becoming undetectable by the latest stages of endosperm development (between 225-255 DAF). In fact, the presence of a mitotic microtubular cytoskeleton up to $120 \mathrm{DAF}$ indicates that the histo-differentiation of the endosperm was accomplished before 120 DAF (Estanislau, 2002). After 150 DAF, only a cortical cytoskeleton was observed indicating the predominance of cellular expansion as characteristic of the final steps of plant seed maturation (De Castro, 1998). As also observed for other plant seeds, the degradation of the cytoskeleton and tubulin subunit proteins follow the dehydration process observed in the last stages of endosperm development (Estanislau, 2002).

Caffeine metabolism: Caffeine metabolism will be treated in detail in a special chapter in this issue (see Ashihara in this issue). However, it appears important to us that a rapid overview be made about key points concerning caffeine metabolism.
In coffee plants, caffeine is actively biosynthesized during leaflet emergence and then decreases when leaves reach their optimal photosynthetic capacity (Frischknecht et al., 1986; Ashihara et al., 1996; Zheng and Ashihara, 2004). In addition to leaves, the incorporation of ${ }^{14} \mathrm{CO}_{2}$ in caffeine detected in perisperm and pericarp shows that these tissues also synthesize caffeine (Keller et al., 1972; Söndahl and Baumann, 2001). The incorporation of [methyl- $\left.{ }^{14} \mathrm{C}\right]$ methionine was much higher (x 25) in the pericarp under light conditions than in the perisperm, suggesting a light-stimulated methylation in the pericarp that could come from methylase enzyme activation or from a light-regulated expression of its

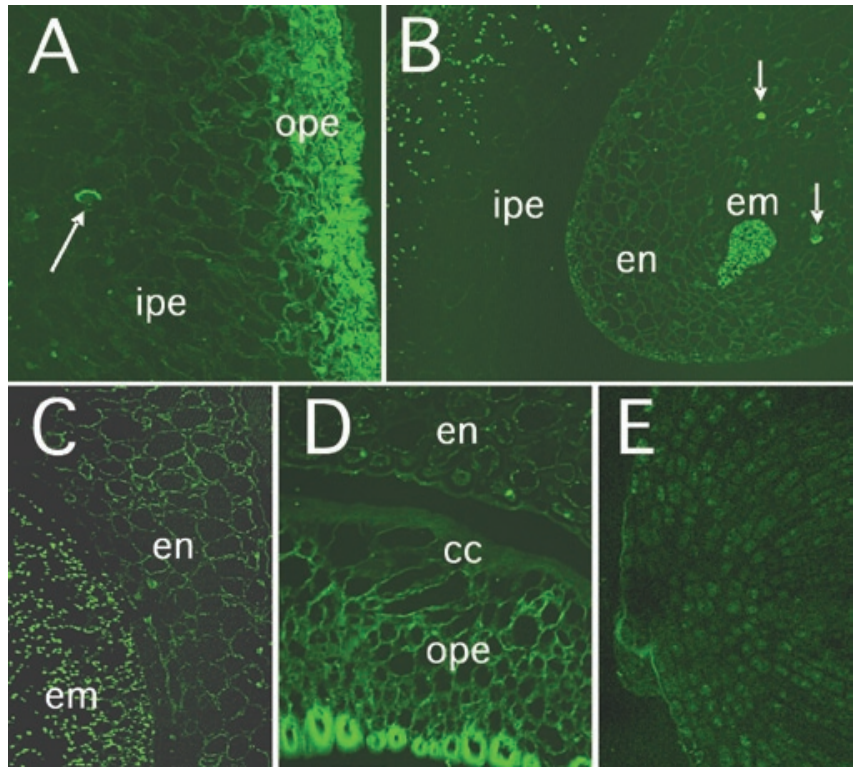

Figure 6. Immunofluorescence (FITC) micrographs showing the microtubular cytoskeleton in coffee ( $C$. arabica var. Acaiá Cerrado MG-1474) seeds. A: Fruits at 90 DAF, showing the intact and growing perisperm, composed of the inner perisperm (ipe) with larger cells and the outer perisperm (ope) with smaller cells. B: Fruits at 90 DAF, showing the initial development of the endosperm (en) which encloses a still undifferentiated globular embryo (em). C: Fruits between 150 and 180 DAF, showing $\beta$-tubulin fluorescence granules as a result of the initial degradation of the cortical microtubular cytoskeleton in the embryo. D: Fruits at 165 DAF showing the endosperm still containing some few granules of $\beta$-tubulin, the compact cuticle (cc) layer of cell wall remnants resulting from the consumption of the inner perisperm. E: Radicle of an embryo from mature cherry fruits at $225 \mathrm{DAF}$, showing the complete absence of microtubular cytoskeleton and $\beta$ tubulin granules. Arrows indicate dividing cells with mitotic microtubular cytoskeleton configurations. Bars indicate 10 $\mu \mathrm{m}$. Data from Estanislau (2002). 
corresponding gene. Caffeine synthesis should also occur in young ("liquid") endosperm of $C$. arabica since it serves as an ideal source for the isolation of $N$-methyltransferases (Mazzafera et al., 1994; Gillies et al., 1995).

Low levels of caffeine were detected in xylem sap of coffee (C. arabica cv. Catuaí "Vermelho") plants, suggesting that it is not highly transported within the plant and that a major part of caffeine synthesis occurs directly in the tissues where it is detected (Mazzafera and Gonçalves, 1999). In seeds, absolute amounts of caffeine parallel the dry weight curve, with more or less constant caffeine content during maturation, nearing $1 \%$ on a dry matter basis (DMB) at the time of harvest. It is interesting to note that the major increase in caffeine content in seeds occurred between the developmental stage 6 ( 8 to $12 \mathrm{WAF}$ ) and 7 (16 WAF) in the Arabica model system analyzed (Keller et al., 1972), corresponding to the time of rapid endosperm expansion. From the developmental stage 7, and up to the harvest stage (stage 11) the caffeine content in the pericarp was constant, suggesting that its biosynthesis stopped or that it continues but with an active transfer to the bean (Baumann and Wanner, 1972).

Although no data are available for enzymatic activities of caffeine synthesis for individual coffee tissues, the above results suggest the existence of tissue-specific expression of genes coding for $N$-methyltransferases (see section "Gene expression during coffee fruit development - genes of caffeine metabolism"). In addition, concerted synthesis of caffeine and chlorogenic acids (mainly 5-CQA) was also reported during coffee leaf development (Baumann et al., 1993; Aerts and Baumann, 1994), and could play an important physiological role by limiting the autotoxicity of caffeine, by reducing its diffusion through the membranes (Mösli-Waldhauser and Baumann, 1996; see Baumann in this issue).

Chlorogenic acids: Chlorogenic acids (CGA) constitute a family of esters formed between transcinnamic acids (caffeic and ferulic) and quinic acid (Clifford, 1985b). These phenolic compounds represent an average of $4.1 \%$ and $11.3 \%$ DMB, respectively for Robusta and Arabica (Ky et al., 2001a), and could explain the flavor differences between these species (Clifford, 1985b; Guyot et al., 1996). Recently, the antioxidant capacity of these chlorogenic acids in animal systems was demonstrated (Daglia et al., 2004), which increased the interest to study CGA pathways in plants (Hoffmann et al., 2003; Niggeweg et al., 2004), including coffee (Campa et al., 2005; Melo and Mazzafera, 2005).
By analyzing clones of $C$. canephora from different geographical regions, Ky et al. (2001a) showed that the origin was a source of intra-specific variations, mainly for percentage of 5-FQA and 4,5-diCQA. In addition, the increase of the CQA/di-CQA ratio was also reported to be as a good marker for coffee bean maturity (Dentan, 1985b). The reasons for these differences are still unknown but could be controlled in part by the hydroxycinnamoyl-CoA: shikimate / quinate hydroxycinnamoyl-transferase (HCT enzyme), which esterifies quinic acids with cinnamic acids (see section "Gene expression during coffee fruit development-genes of CGA pathway").

The analysis of chlorogenic acids during the development of both leaves and fruits of C. pseudozanguebariae, showed that CGA contents were equal in leaves and fruits when both tissues were at young developmental stages, i.e. leaf length less than $40 \mathrm{~mm}$ and fruits with perisperm predominating (Bertrand et al., 2003). However, when the endosperm begins to develop, a substantial increase of CGA content was observed, mainly characterized by the accumulation of CQAs (3-CQA: 3-caffeoylquinic acid; 4-CQA: 4caffeoylquinic acid and 5-CQA: 5-caffeoylquinic acid) in coffee beans. High quinic acid content was also detected in the initial developmental stages of grain (perisperm and endosperm), between 6 and $16 \%$ of dry weight for Arabica and Robusta coffees (Rogers et al., 1999b; Marraccini et al., 2001a). Towards the end of seed development, these levels were shown to decrease drastically in both species, again arguing for a stimulation of CGA metabolism in the endosperm, mainly oriented towards CQA accumulation (Bertrand et al., 2003).

Trigonelline synthesis: Trigonelline is synthesized through the methylation of nicotinic acid (NAD) by S-adenosyl-Lmethionine (SAM)-dependent nicotinate $N$-methyltransferase (EC2.1.1.7). Its function is still a matter of debate but it might be a reserve compound for NAD that could be used during germination (Shimizu and Mazzafera, 2000). During roasting, trigonelline alkaloid gives rise to many aroma (flavor) compounds, like alkyl-pyridines and pyrroles (De Maria et al., 1994), which explains the interest of breeding programs to increase of trigonelline content in Robusta green beans (Ky et al., 2001b).

In contrast to caffeine, trigonelline is synthesized in all parts of coffee seedlings but accumulated to higher levels in young tissues, such as leaves and flower buds, as well as in pericarp and beans (Zheng et al., 2004; Zheng and 
Ashihara, 2004, see Ashihara in this issue). Using [carbonyl- ${ }^{14} \mathrm{C}$ ]nicotinamide as a precursor, Zheng et al. (2004) showed that trigonelline was synthesized in the pericarp of unripe fruits but declined as fruits ripen. Although no tissue separation was made in this study, most of the trigonelline synthesis activity was detected in the "endosperm" stage of coffee seeds. In fully ripe seeds, high trigonelline accumulation was observed even if no synthesis activity was detected. This suggested that net biosynthesis of trigonelline takes place in the pericarp and that trigonelline may be further transported from this tissue to the endosperm. Interestingly, genetic variability was observed in coffee for trigonelline content, with Arabica ranging from 0.88 to $1.77 \%$ of DMB and Robusta with 0.75 to $1.24 \%$ of DMB (Ky et al., 2001a). Different trigonelline contents were also reported for $C$. pseudozanguebariae (PSE) and C. liberica var. Dewevrei (DEW) respectively with $1.02 \%$ and $0.57 \%$ of DMB (Ky et al., 2001b). Using a PSE x DEW cross between these two species, the same authors identified one nuclear quantitative trait loci (QTL) for trigonelline content and located it on the G linkage map (Ky et al., 2001b). The identification of EST (Expressed Sequenced Tag) sequences coding for nicotinamidase (EC 3.5.1.19) and nicotinate N-methyltransferase (EC 2.1.1.7) should help to reveal whether the variations of trigonelline contents observed in these species can be explained by differential expression of these genes.

Diterpene metabolism: Despite of their important role in flavor stability and release, coffee lipids have been very little studied (see Speer and Kölling-Speer in this issue). They range from $15 \%$ of dry weight in coffee beans of Arabica to $10 \%$ in Robusta commercial species, but are subject to a larger variation depending on origin and varieties, for example with 8-9\% of dry weight in C. liberica to $30 \%$ in $C$. salvatrix (Picard et al., 1984; Speer et al., 1993; Mazzafera et al., 1998). As cited above, it was proposed that the better cup quality of coffee grown at higher altitudes was linked to higher "fat matter" content of beans (Decazy et al., 2003; Vaast et al., 2006), although it is not known how the lipid composition was affected.

Within lipids, diterpenes (cafestol: $\mathrm{C}_{20} \mathrm{H}_{28} \mathrm{O}_{3}$ and kahweol: $\mathrm{C}_{20} \mathrm{H}_{26} \mathrm{O}_{3}$ ) represent $10 \%$ of coffee oil and are specific of the coffee genus (Speer and Kölling-Speer, 2001). Although no biological functions have been assigned, both cafestol and kahweol are of particular interest, especially in human health where they are considered to stimulate cholesterol synthesis (Urgert et al., 1997; Post et al., 2000; De Roos et al., 2001), and also reported to give protection against some types of cancer (Lam et al., 1982, Cavin et al., 1998). A great diversity was observed for diterpene content both at the interspecific (De Roos et al., 1997; Mazzafera et al., 1998) and intraspecific levels (Speer and Kölling-Speer, 2001), suggesting the existence of genetic polymorphism of the enzymes controlling the cafestol / kahweol biosynthesis pathways.

Preliminary observations suggested that key steps of the diterpene biosynthesis are restricted to specific tissues in coffee (Kölling-Speer and Speer, 1997). For example, cafestol is the main diterpene detected in leaves of both Arabica and Robusta, whereas kahweol is undetectable in this latter species. Kahweol is also undetected in the pericarp of Arabica fruits, but accumulates to high level in endosperm. Green beans of $C$. canephora do not contain kahweol but accumulate another diterpene, 16 O-methyl cafestol that is not encountered in Arabica. Based on these results, one might predict the existence of a "kahweolsynthase" enzyme specifically expressed in C. arabica seeds, and of a "cafestol-methylase", responsible of the 16-OMC biosynthesis, specifically in C. canephora seeds. The identification of genes coding for these enzymes and for those of the isoprenoid biosynthesis pathway (Liu et al., 2005) should be facilitated by the screening of UniGene membranes of the Brazilian Coffee Genome Project (see Vieira et al., in this issue).

Coffee storage proteins and free amino acids: At the cup quality level, amino acids are also important because they react with sugar moieties through "Maillard" reactions (Maillard, 1912) to produce aromatic compounds. Among these, glutamic acid and asparagine are the most abundant, representing near $40 \%$ of free amino acids in coffee beans (Poisson, 1977; Arnold et al., 1994; Arnold and Ludwig, 1996). Both are also the major forms of nitrogen transport in xylem sap of coffee (Mazzafera and Gonçalves, 1999). Some differences exist in the composition of free amino acids in green coffee beans of different species, for example with glutamic acid content being higher in Arabica than in Robusta (Arnold et al., 1994).

There are also several reports on the importance of proteins in beverage quality (Amorim et al., 1975; Melo and Amorim, 1975; Arnold and Ludwig, 1996; Montavon et al., 2003). In mature beans of $C$. arabica var. Caturra, protein content represents $10 \%$ of dry weight with $45 \%$ of them being related to $11 \mathrm{~S}$ legumin storage proteins (Rogers et al., 1999a). By SDS-PAGE (SDS-polyacrylamide gel electro- 
phoresis) analysis, Baú et al. (2001) identified the presence of 11S-type storage proteins in various coffee species, except in C. racemosa where storage proteins of lower molecular weight were observed. Independent of the coffee species studied (Arabica or Robusta), 11S storage proteins were not detected in perisperm tissue (figure 3), but specifically at the time of rapid endosperm expansion (Rogers et al. 1999a). Although to a lesser extent, accumulation of $11 \mathrm{~S}$ storage proteins was also reported in both zygotic and somatic embryos (Yuffá et al., 1994).

Comparison of amino acid sequences of $11 \mathrm{~S}$ protein deduced from cloned full-length cDNAs reveals the existence of some differences that could not explain the variations of $\mathrm{pI}$ and of molecular weight usually observed by SDS-PAGE (Acuña et al., 1999; Baú et al., 2001) or 2D-gel electrophoresis (Rogers et al., 1999a). At the amino acid level, 11S storage proteins are relatively rich in glutamine, glycine, leucine and acid glutamic amino acid residues, respectively with $11 \%$, $10 \%, 9 \%$ and $7.5 \%$ of total molecular weight. Their content is relatively low in the sulfur amino acids cysteine $(1 \%)$ and methionine $(0.6 \%)$, suggesting a limited role of these amino acids as precursors of aromas and flavors in coffee (Grosch, 2001).

When the amino acid composition of $11 \mathrm{~S}$ proteins was compared with the composition of free amino acids in coffee beans, no obvious correlations were observed (Poisson, 1977; Arnold et al., 1994; Arnold and Ludwig, 1996). This argues for a little influence of 11S storage proteins in the control of the pool of free amino acids. However, differences of 11Sprotein profiles (SDS-PAGE and 2D-gel electrophoresis) were observed between Arabica and Robusta, as for Ugandan and Congolese varieties (Rogers et al., 1999a), and also in other species, such as C. liberica and dewevrei (Baú et al., 2001), suggesting the existence of several types of $11 \mathrm{~S}$ proteins in the coffee genus.

Finally, post-harvest treatments were also reported to influence amino acid contents in coffee beans, for example, the higher levels of L-alanine found in beans of C. arabica processed by the dry method (Ludwig and Arnold, 1996; Casal et al., 2001). The origin of these variations is still unknown but could be due to the action of specific-proteases as described below. Because storage proteins seem to be encoded by a limited number of genes (Acuña et al., 1999; Lin et al., 2005), the analysis of 11S-cDNA sequences from different coffee species and cultivars should be interesting to provide an in depth view of their amino acid composition.
Proteases: In cocoa, specific aroma precursors are derived preferentially from the vicilin-class (7S) globulin storage protein, via its successive degradation by an aspartic protease and a carboxypeptidase (Voigt et al., 1994). Recently, beans from C. arabica cv. Obatã grown in the state of São Paulo (Brazil), in a location with relatively higher annual mean temperature (23. $1^{\circ} \mathrm{C}$, Adamantina), were shown to contain higher protease activities, total protein and free amino acids than beans from the same cultivar grown in other locations of lower annual mean temperatures $\left(21.8^{\circ} \mathrm{C}\right.$, Mococa; $20.7^{\circ} \mathrm{C}$, Campinas) (Silva, 2004; Silva et al., 2005). Sensorial evaluations showed that beans from Adamantina had lower beverage quality than beans from the other two locations, suggesting a negative correlation between protease activities and cup quality.

It has been considered that there is no clear proof that coffee storage proteins can act as flavor or aroma precursors through their degradation by specific proteases (Montavon et al., 2003). Nevertheless, 2D-gel electrophoresis and $\mathrm{N}$-terminal sequencing studies clearly demonstrate that abundant peptides of 12 to $16 \mathrm{kDa}$ found in protein extracts of mature coffee beans correspond to degradation products of the $\alpha$ subunit of 11S storage proteins (Rogers et al., 1999a). Ludwig et al. (2000) also identified low molecular weight peptides (ranging from 4 to $12.5 \mathrm{kDa}$ ) that accumulated differentially in beans of $C$. arabica and $C$. canephora. The origin of these polypeptides is unknown, but part of them could also correspond to degradation products of $11 \mathrm{~S}$ storage proteins by particular peptidases. Such enzymes could also be responsible for higher amino acid contents usually detected in washed coffee beans (Casal et al., 2001; Selmar et al., 2001), which are known to have a better cup quality than beans processed by the dry method. Proteases activities were reported in mature beans of Arabica and Robusta coffee species (Ludwig et al., 2000).

Altogether these observations have increased the interest in the search for protease-encoding cDNA sequences (Ben Amor et al., 2003; Baptista et al., 2005). Hence, more than 1,800 "protease-encoding" ESTs were identified from the Brazilian Coffee Genome Project and arranged in 18, 13, 13 and 10 clusters for cysteine-, aspartic-, metal- and serineproteases respectively (Baptista et al., 2005). The availability of protease-encoding sequences should now permit the analysis of the influence of environmental conditions and post-harvest treatments on their gene expression.

Sucrose metabolism during coffee fruit development: Sucrose is another important compound for coffee cup qual- 
ity because it is rapidly degraded during roasting, to give anhydro-sugars and other compounds like glyoxal (Clifford, 1985a; De Maria et al., 1994). These molecules are then able to react with amino acids to produce aliphatic acids, hydroxymethylfurfural and other furans, pyrazine and carbonyl compounds, which are essential contributors to coffee flavor, either as volatile aroma compounds, or as non-volatile taste compounds (Grosch, 2001; Homma, 2001).

Differences of sucrose content in commercial species of coffee are well known, with means of $9.4 \%$ and $6 \%$ DMB of sucrose, respectively for beans of $C$. arabica and $C$. robusta (Ky et al., 2001a; Campa et al. 2004). The first attempt to analyze sucrose metabolism in isolated tissues of coffee was made by Rogers et al. (1999b), who showed that reducing sugar (i.e. glucose and fructose) content decreased in the perisperm concomitantly with its disappearance, whereas sucrose content increased gradually within the developing endosperm. In addition, levels of reducing sugars in the perisperm were higher in C. arabica than in C. canephora which could explain in part the differences in sucrose content observed in mature endosperm of these species.

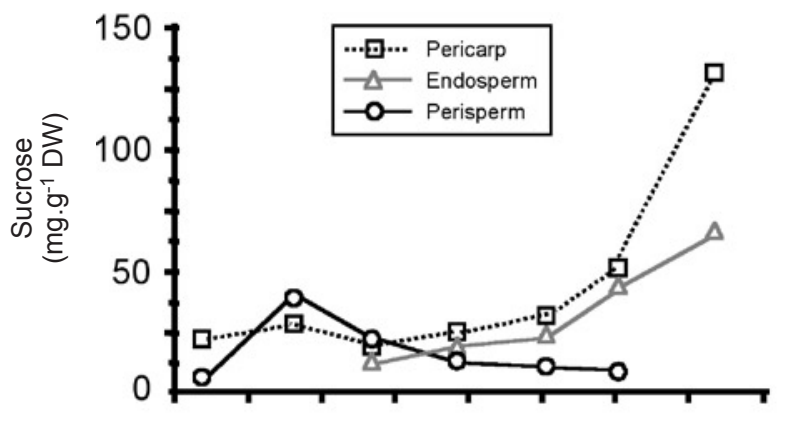

A

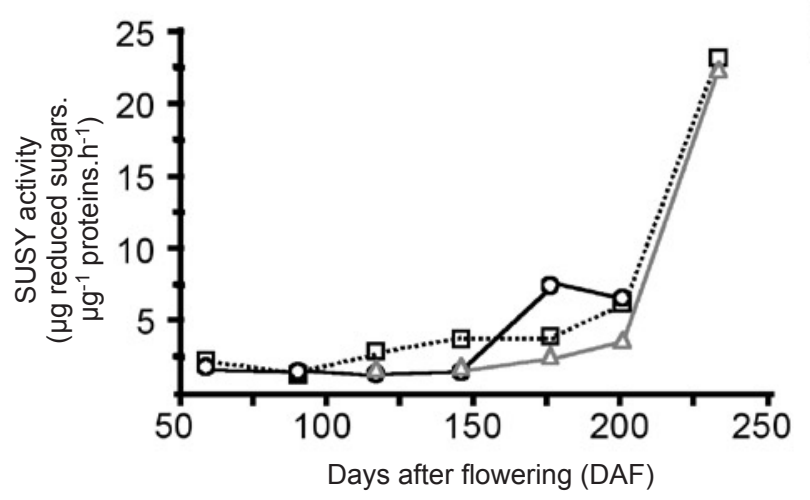

Figure 7. Evolution of sucrose concentration (sucose igual) (A) and SUS enzymatic activities ( $\mu \mathrm{g}$ of sucrose reduced $\mu \mathrm{g}^{-1}$ proteins. $\mathrm{h}^{-1}$ ) (B) in separated tissues of fruits from C. arabica var. Iapar 59 (from Geromel et al., submitted).
Recently, Geromel et al. (2005) refined this previous work by analyzing sugar contents and enzymatic activities in separated tissues (pericarp, perisperm and endosperm) of developing fruits of C. arabica var. Iapar 59. High hexose to sucrose ratios were observed during early stages of perisperm (90 DAF) and endosperm (120 DAF) development (figure 7), which is a characteristic in tissues with intense cell division activity (Weber et al., 1998). In the perisperm, the inversion of this ratio between 120 to 176 DAF accompanied the gradual disappearance of this tissue, and coincided with the beginning of endosperm expansion. In the latter, the transition from high to low hexose to sucrose ratio observed between 147 and 176 DAF marks the shift between the expansion and storage phase, also characterized by the accumulation of storage proteins and sucrose in the endosperm (Rogers et al., 1999a; Geromel et al., 2005). In the pericarp, reducing sugars and sucrose accumulated slowly to similar levels up to 176 DAF. During the two latter months of fruit maturation (176 to 234 DAF), a large and rapid accumulation of reducing sugars and sucrose was observed, respectively with concentrations near 280 and $180 \mathrm{mg} . \mathrm{g}^{-1} \mathrm{DMB}$ at the time of harvest, thus confirming other observations showing a gradual increase of soluble solids during the maturation of the pericarp (MarínLópez et al., 2003). Initial data concerning the identification of genes coding for sugar-metabolizing enzymes implicated in this process will be presented below (see section "Gene expression during coffee fruit development-genes of sucrose metabolism").

Polyphenol oxidase (EC 1.10.3.2): The oxidation of polyphenols (mainly CGA) occurs either by an autoxidation process (Cilliers and Singleton, 1991), or enzymatically by the action of polyphenol oxidases (Amorim and Silva, 1968; Mazzafera and Robinson, 2000). This leads to semiquinones and quinones that could play a defensive role by reducing the nutritive value of plant tissues wounded by herbivores (Mazzafera and Robinson, 2000). On the other hand, quinones may also react with amino acids and proteins (Mason, 1955) and thereby play a direct role in coffee cup quality. In this regard, several studies have shown that coffee of low beverage quality correlates with low polyphenol oxidase (PPO) activities in green beans (Amorim and Silva 1968; Amorim and Amorim, 1977), and likewise for coffee maintained under bad storage conditions (Begnami et al., 1999). In this case, low beverage quality was proposed to result from ultra-structural (membrane) damage leading to PPO inhibition by quinines arising from the oxidation of 
chlorogenic acids, but not from PPO activity per se (Clifford, 1985a, 1985b).

Whatever their mode of action, PPOs are important enzymes in coffee and have been characterized in leaves (PPO-L) and in developing endosperm (PPO-E) where high enzymatic activities were found (Mazzafera and Robinson, 2000). Enzymatic activities of PPO-L were very high in young leaves and declined when length of leaves increased. An inverse situation was observed during coffee bean development, where low PPO-E activities were observed in endosperm at around 100 DAF. As the endosperm develops, PPO-E activities increased to reach a peak at around 170 $\mathrm{DAF}$, and declined slightly in mature beans. Interestingly, PPO activities followed the synthesis of their substrate (CGA) both in leaves and endosperm (Melo and Mazzafera, 2005). Despite the fact that PPO-L and PPO-E differed in molecular weight (respectively $46 \mathrm{kDa}$ and $50 \mathrm{kDa}$ ) and in sensitivity to temperature, Mazzafera and Robinson (2000) suggested that they could correspond to closely related proteins or originate from the same precursor subjected to different post-translational modifications. The search for PPO-encoding ESTs should be very helpful to elucidate their origin as well as to analyze their expression in different storage or environmental conditions.

\section{Gene expression during coffee fruit development}

As previously mentioned, some coffee biochemical pathways (i.e. caffeine) have been studied a very long time whereas others have been poorly investigated. Although limited, the objective of this section is to regroup this information, particularly in the light of recently published articles.

Genes of caffeine metabolism: Three steps of methylation are necessary to produce caffeine from xanthine, implicating successively the action of 7-methylxanthosine synthase (xanthosine $>7$-methylxanthosine), theobromine synthase (7-methylxanthine $>$ theobromine or 3,7-dimethylxanthine) and caffeine synthase (theobromine $>$ caffeine or 1,3,7-trimethylxanthine), using the S-adenosyl-L-methionine (SAM) as a donor of methyl groups. Several studies have been published dealing with gene cloning, expression analysis and protein studies of enzymes from the caffeine biosynthetic pathway (Moisyadi et al., 1998, 1999; Ogawa et al., 2001; Mizuno et al., 2003a,b; Uefuji et al., 2003).

In some cases, expression analyses were made without separating perisperm, endosperm and pericarp tissues or giving information about dates, time and mode of harvest, which renders the interpretation of the results rather difficult in the sense of tissue-specific gene expression. In a recent article, Lin et al. (2005) reported the presence of a unigene (\#122206) from Robusta, coding for a putative S-adenosylL-methionine synthetase and formed by the compilation of 130 ESTs exclusively expressed in earlier stages (18-22 WAF) of cherry development. On the other hand, expression analyses of $N$-methyltransferase cDNA sequences mainly performed by RT-PCR, as well as by classical Northern-blot experiments, showed that the 7-methylxanthosine synthase encoding gene (designated CaXMT1 by Uefuji et al., 2003 or CmXRS1 by Mizuno et al., 2003b) was expressed to equal levels both in developing endosperm and in young leaves. Genes coding for the theobromine synthase (designated CaMXMT1 of CaMXMT2 by Uefuji et al., 2003 or CTS1 and CTS2 by Mizuno et al., 2003a) and caffeine synthase (designated CaDXMT1 by Uefuji et al., 2003 or CCS1 by Mizuno et al., 2003a) were also expressed in immature coffee fruits (as in stage 6-7 corresponding to endosperm expansion; Keller et al., 1972). In addition, the CTS2 gene expression appeared high not only in whole small green fruits (diameter $10 \mathrm{~mm}$ ) but also in the pericarp and immature endosperm of larger fruits (diameter $15 \mathrm{~mm}$ ) (Mizuno et al., 2003a). Interestingly, RT-PCR experiments did not reveal expression of CaXMT1, CaMXMT1, CaMXMT2 and CaDXMT1 genes in mature (stage 10; Keller et al., 1972) fruits (Uefuji et al., 2003), which could explain the absence of caffeine accumulation during the final ripening process (stages 9 to 11; Keller et al., 1972). Expression of CaXMT1, CtCS1, CaMXMT1, CaMXMT2 genes was also detected in tissues rich in dividing cells, as in young leaves and flower buds, where $N$-methyltransferases were previously found to be abundant.

The availability of these cDNA sequences now opens the way to study their nucleic polymorphism and should facilitate the understanding of the genetic variability existing for caffeine content in the coffee genus (Ky et al., 2001a). Recently, transgenic coffee plants with reduced expression of the CaMXMT1 gene were obtained (Ogita et al., 2004). Their analysis showed that they also have reduced expression of CaXMT1 and CaDXMT1 genes in leaves concomitant to a reduction of theobromine and caffeine contents. Work is now under way to verify whether caffeine contents are also reduced in beans produced by these transgenic plants.

Genes coding for storage proteins: In beans of $C$. arabica var. Caturra, the comparison of 2-D gel electrophoresis 
profiles showed that $11 \mathrm{~S}$ proteins began to accumulate at 18 WAF, reaching a maximum at $27 \mathrm{WAF}$ (figure 3 ). In parallel, the expression of the $11 \mathrm{~S}$-encoding gene began at $18 \mathrm{WAF}$ reaching a peak between 22 and 27 WAF. Subsequently, the expression of the cspl gene (hereafter renamed CaCSP1) ceased, becoming undetectable in the mature endosperm (35 WAF in that study). At the same time, a large amount of $11 \mathrm{~S}$ storage proteins was shown to persist, despite slight protein degradation being noted in mature grains. The CaCSP1 gene expression overlapped the accumulation of $11 \mathrm{~S}$ storage proteins and showed tight coupling between transcriptional and translational processes. Although perisperm and endosperm tissues were not separated in this study, the expression profiles obtained strongly suggest endospermspecific expression of storage proteins (figure 8A). This tissue-specificity of $C a C S P 1$ gene expression was also confirmed by RT-PCR experiments (figure $8 \mathrm{~B}$ ), and by the large accumulation of $C a C S P 1$ homologous ESTs found only in fruit cDNA libraries from Arabica (table 1) and Robusta (Lin et al., 2005). This endosperm-specific expression of the CaCSP1 gene is under the transcriptional control of a promoter region able to direct the expression of the GUS reporter gene only in endosperm of transgenic tobacco seeds (Marraccini et al., 1999).

Lin et al. (2005) also identified a unigene (\# 125230) coding for putative $2 \mathrm{~S}$ storage proteins formed by the clusterization of 1219 ESTs mainly expressed during the middle stages $(\approx 30 \mathrm{WAF}$ ) of Robusta seed development. However, a lower level of 2S-encoding ESTs was detected in the last stage of seed development (42-46 WAF), at the time when ESTs for 11S storage proteins were strongly detected. Up to now, $2 \mathrm{~S}$ proteins have not been identified by $2 \mathrm{D}$-gel electrophoresis in protein extracts of mature seeds of Arabica and Robusta (J.W. Rogers, personal communication), suggesting that they could be transiently synthesized during seed development in these two species. However, they could correspond to the low molecular weight $(<10 \mathrm{kDa})$ proteins strongly detected in mature seeds of $C$. racemosa (Baú et al., 2001, P. Mazzafera, personal communication).

Analysis of $\alpha$-D-galactosidase expression: $\alpha$-D-galactosidase ( $\alpha$-Gal; EC 3.2.1.22) is a very abundant protein in mature coffee beans (see Sigma-Aldrich catalog ref G8507) and was one of the first plant $\alpha$-D-galactosidases to be characterized (Courtois and Petek, 1966; Carchon and De Bruyne, 1975; Haibach et al., 1991). It acts on galactomannans by removing galactose residues at the O- 6 position of the $(1 \rightarrow 4)-\beta$ - man- nan chain to give insoluble mannans. For this reason, it was proposed to be one of the main enzymes involved in the deposition of mannans in cell walls (Redgwell et al., 2003). This enzyme also attracted attention in the field of biotechnology due to its capacity to remove the terminal galactose units $(\alpha$ $1 \rightarrow 3$ linked) from the blood group B cell surface carbohy-
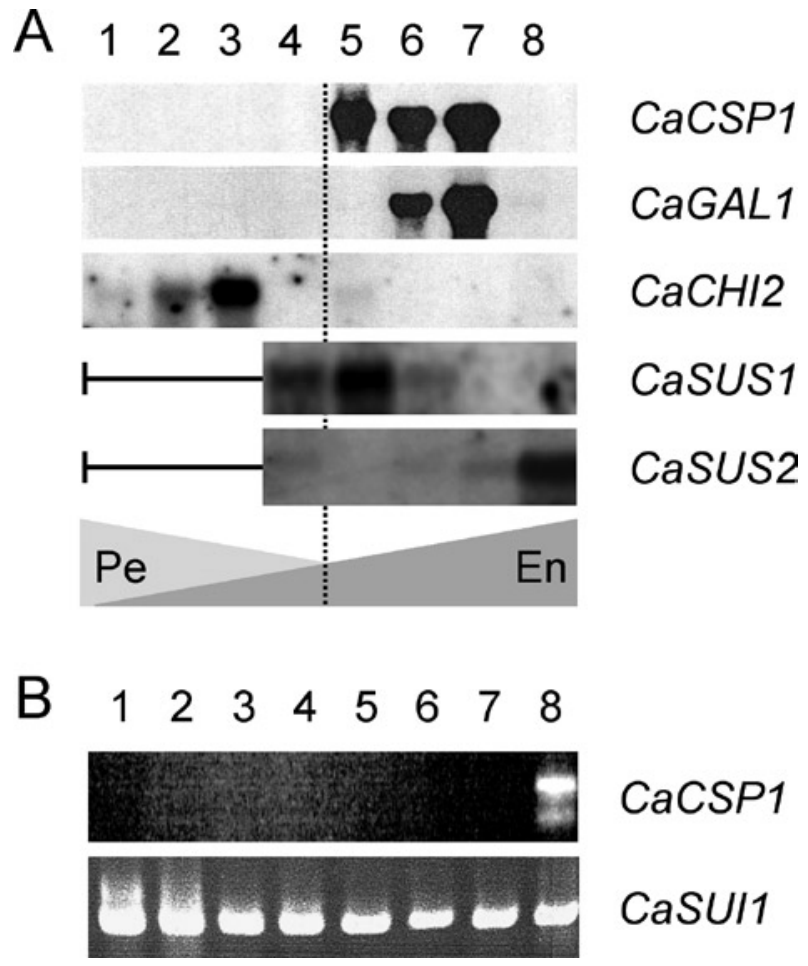

Figure 8. Example of genes expressed during bean development in $C$. arabica. A: Total RNAs were extracted from whole seeds (perisperm and endosperm) and probed by ${ }^{32} \mathrm{P}$ labelled cDNA of 11S storage proteins (CaCSP1, Y16976: Rogers et al., 1999a), $\alpha$-galactosidase (CaGAL1, AJ877911: Marraccini et al., 2005) and class III chitinase ( $\mathrm{CaCHI2}$, AM159173). For CaSUS1 (AM087674) and CaSUS2 (AM087675) expression analysis, total RNAs were extracted from separated perisperm and endosperm tissues (Geromel et al., submitted). Fruits were harvested at 28 DAF (lane 1); 49 DAF (lane 2); 63 DAF (lane 3); 98 DAF (lane 4); 126 DAF (lane 5); 154 DAF (lane 6); 189 DAF (lane 7) and 245 DAF WAF (lane 8). The broken vertical line indicates the virtual separation between "perisperm-phase (Pe)" (0-120 DAF) and "endosperm phase (En)" ( $\approx 120$ DAF up to the harvest). $\mathrm{B}$ : Analysis of CaCSP1 gene expression in different coffee tissues by RT-PCR. For CaSUI1, experimental conditions were previously described (Gaborit et al., 2003). RT-PCR conditions used for amplification of $C a C S P 1$ were identical to those for used CaSUI1, except that SO11 and SO2-1 primers were used (Marraccini et al., 1999). Lanes: 1, young leaves $(<1 \mathrm{~cm})$; 2 , intermediate leaves (length $2-5 \mathrm{~cm}) ; 3$, old leaves ( $>5 \mathrm{~cm})$; 4 , flowers buds; 5 , open flowers; 6 , stems; 7 , roots 8 , beans at $189 \mathrm{DAF}$. 

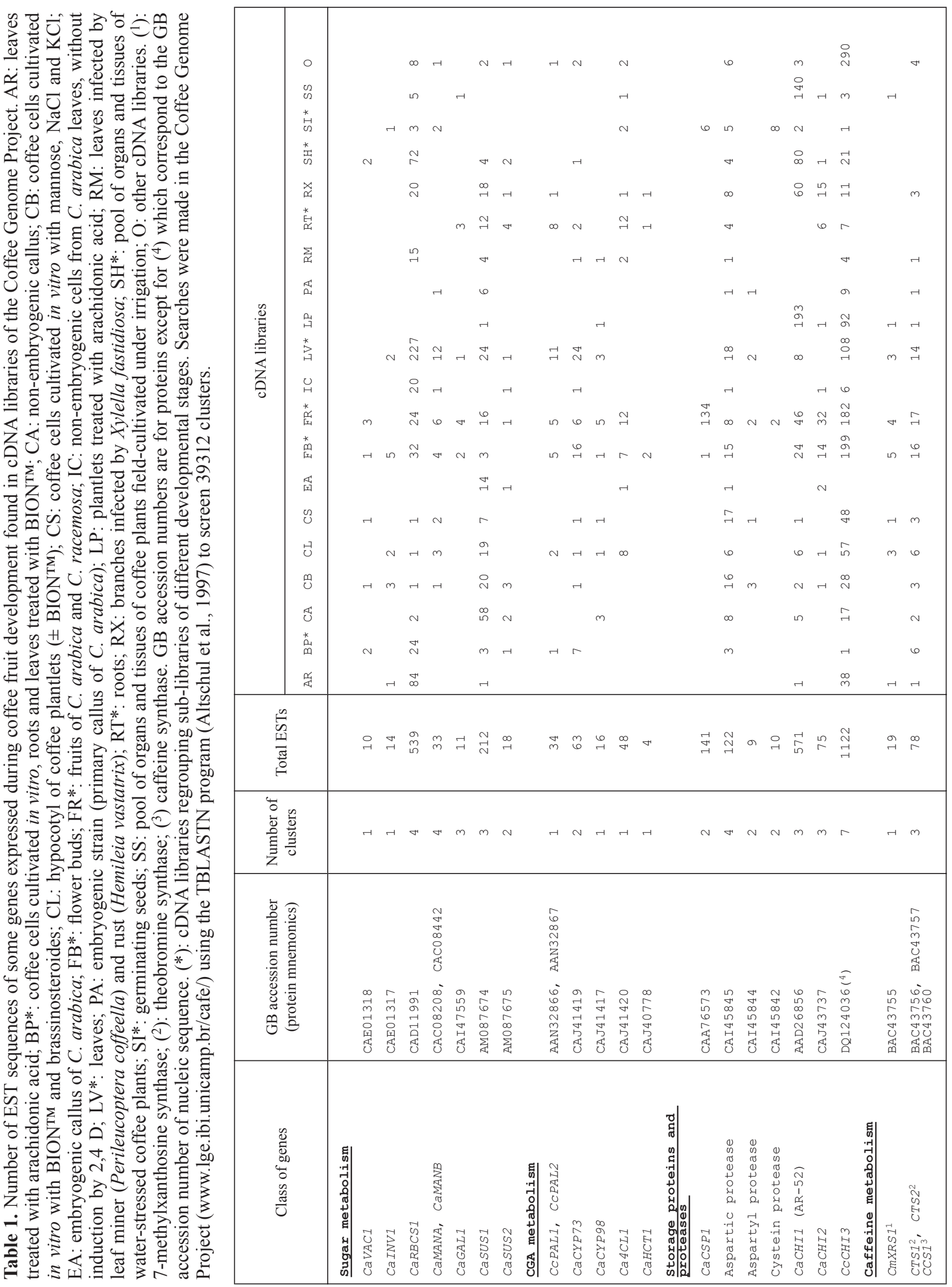

Braz. J. Plant Physiol., 18(1):175-199, 2006 
drate moiety of glycoprotein complexes, thus generating type O red blood cells (Yatsiv and Flowers, 1971).

Coffee tissues (perisperm and endosperm) were separated during the maturation of fruits of $C$. arabica var. Caturra to analyze $\alpha$-Gal enzymatic activity and gene expression (Marraccini et al., 2005). $\alpha$-Gal activity was not detected in perisperm tissue but increased gradually with endosperm development, to reach a peak at $30 \mathrm{WAF}$ that coincided with the maximal of $\alpha$-Gal activity in whole coffee berries at the semi-ripe (yellow exocarp) developmental stage (Golden et al., 1993). Northern-blot experiments detected $\alpha$-Gal transcripts at 22 and 27 WAF, overlapping $\alpha$-Gal enzymatic activity detected at the same time in the endosperm. In mature beans, $\alpha$-Gal gene expression was undetectable, despite the high activity persisting at this stage.

As for endo- $\beta$-mannanase (Marraccini et al., 2001b), high $\alpha$-Gal activity was also detected during in vitro germination of coffee beans of $C$. arabica var. Caturra, with a continuous increase from 0 to 40 days after imbibition (Marraccini et al., 2005). Because expression analysis was not performed, it is not yet known whether this high $\alpha$-Gal activity detected during germination arose from the expression of the CaGAL1 gene or of other $\alpha$-D-galactosidase-encoding genes.

Genes of the CGA pathway: The biosynthetic pathway of CGA in coffee should involve at least five different enzymes: PAL (phenylalanine ammonia-lyase), C4H (cinnamate-4hydroxylase), 4CL (4-[hydroxy]cinnamoyl-CoA ligase), $\mathrm{C} 3 \mathrm{H}$ (p-coumaroyl-shikimate/quinate 3'-hydroxylase) and HCT (hydroxycinnamoyl CoA: quinate hydroxycinnamoyl transferases) (Campa et al., 2003; Hoffmann et al., 2003).

In coffee, PAL enzymatic activity was light-stimulated in cell suspensions of C. arabica (Baumann et al., 1993) and also strongly detected in young leaflets but decreased during further leaf expansion (Aerts and Baumann, 1994). To the authors' knowledge, no work has been published concerning measurements of enzymatic activities of the CGA pathway, either in whole or separated tissues of coffee fruits.

However, the availability of EST coffee sequences (see Vieira et al., in this issue) permits the search of genes coding for these enzymes. Consequently, preliminary results of EST clusterization led us to conclude that there are at least three clusters coding for phenylalanine ammonia-lyase in coffee (named CaPAL1-3) as well as for the 4CL enzyme (named Ca4CL1-3). A unique cluster should code for the $\mathrm{C} 3 \mathrm{H}$ enzyme ( $\mathrm{CaCYP98),} \mathrm{whereas} \mathrm{at} \mathrm{least} \mathrm{two} \mathrm{clusters} \mathrm{were}$ found for the $\mathrm{C} 4 \mathrm{H}$ enzyme (CaCYP73) (table 1). The highest degree of complexity was encountered for the HCT enzyme that seems to be coded by at least 8 different clusters, named from CaHCT1 to 8 (G. Melo and E.K. Takahashi, personal communication).

Specific primer sets were designed from clusters formed by ESTs preferentially encountered in fruit cDNA libraries, and used in RT-PCR experiments to analyze gene expression during endosperm and leaf development in C. arabica (Melo, 2005; Melo and Mazzafera, 2005). For each cluster tested (PAL, C4H, C3H, 4CL and HCT), expression declined as the endosperm and leaf aged, concomitantly with the decrease in 5CQA content. The same kind of approach was followed to study gene expression in whole fruits of $C$. canephora under development (Campa et al., 2005). In that case, two cDNAs were identified for PAL and $\mathrm{C} 3 \mathrm{H}$ enzymes (respectively called PAL-1 and 2 and $\mathrm{C} 3$ ' $\mathrm{H}-\mathrm{C} 1$ and 2, according to the authors' nomenclature), and used to design primer sets for RT-PCR experiments. This showed that PAL-1 and C3'H$\mathrm{C} 1$ genes were expressed independently of fruit maturation (from green to red exocarp), whereas the PAL-2 and C3'HC2 genes were only expressed in the "red pulp" stage of fruit development. It is difficult to compare these data with those obtained in C. arabica due to the absence of tissue separation and the limited number of development stages analyzed. Other analyses are underway to obtain a better overview of gene expression of CGA biosynthetic enzymes in $C$. canephora (A. De Kochko, personal communication).

Recently, a full-length cDNA sequence from $C$. arabica homologous to the HCT enzyme from Nicotiana tabacum (Hoffmann et al., 2003) was cloned and named CaHCT1 (G. Melo, L.P. Ferreira, L.G. Vieira, P. Marraccini, P. Mazzafera, unpublished observations). Northern-blot analysis revealed that this gene was expressed in endosperm of $C$. arabica, with a pattern identical to that observed for $11 \mathrm{~S}$ - and $\alpha$-Dgalactosidase-encoding genes. To confirm the implication of CaHCT1 gene in CGA synthesis, it would be interesting to test its expression in fruits of $C$. pseudozanguebariae since CGA metabolism was shown to be oriented towards CQA accumulation in this coffee species (Bertrand et al., 2003).

Genes of sucrose metabolism: Two full-length cDNAs coding for the sucrose synthase (SUS: EC 2.4.1.13) from $C$. arabica have been cloned and characterized (Geromel et al., submitted). These cDNA, named CaSUS1 and CaSUS2, are identical in length but encode proteins that only share $68 \%$ of identity, suggesting that they assume different functions in sucrose metabolism during the maturation of coffee fruits. 
Northern-blots showed that the CaSUS1 gene was expressed at early stages of endosperm development, at the time of rapid cellular expansion (figure 8). However, high expression of CaSUS2 was only observed during the latest stages of endosperm development, which coincides with maximal of SUS activity (Geromel et al., 2005). Because CaSUS2 expression also overlapped the peak of sucrose in these tissues (figures 7A and 7B), the CaSUS2 isoform of SUS protein was proposed to be the main enzyme responsible for sucrose accumulation in coffee seeds.

The CaSUS1 isoform of SUS could function in the sense of sucrose degradation since its expression was never accompanied by sucrose accumulation (Geromel, 2002; Geromel et al., 2005). In addition, preliminary studies showed that CaSUS1 gene expression was higher in perisperm and endosperm tissues of beans grown in shade conditions compared to fruits kept in "full sun" conditions (L.P. Ferreira and P. Marraccini, unpublished observations). Taken together with the maintenance of high hexose to sucrose ratio for a longer period in the shade plant, favoring cell division and elongation in young perisperm and endosperm tissues, this could explain the larger bean size observed for coffee plants cultivated under this condition (Muschler, 2001; Vaast et al, 2006). Additional experiments are underway to analyze sugar content, SUSY activity and gene expression in fruits of Coffea species of different bean size. In addition, CcSUS1 and CaSUS2 genes have been cloned, respectively from $C$. canephora (Leroy et al., 2005) and C. arabica (Geromel et al., submitted). Both are presently under analysis, particularly to study their nucleic polymorphism in various coffee species differing by their sucrose content in mature beans (Bouchet et al., 2005).

Genes expressed during pericarp maturation: In coffee, the lack of uniform ripening has serious effects on coffee quality when immature fruits are harvested together with mature fruit. It has been demonstrated that coffee fruit ripening could be synchronized by the exogenous application of ethephon during early (10-20\% of fruit colored) fruit development (Crisosto et al., 1990, 1992; Winston et al., 1992). This demonstrates that ethylene controls the final ripening stages of coffee fruit development and has motivated the search of genes coding for ethylene biosynthesis with the aim of reducing ethylene formation in the pericarp of genetically modified coffee plants (Neupane et al., 1999; Stiles, 2001).

cDNA sequences coding for ACC (1-aminocyclopropane1-carboxylic acid) oxidase and ACC synthase have been cloned (Neupane et al., 1999; Galvão et al., 2001; Pereira et al., 2005). In C. arabica, the ACC oxidase ( $\mathrm{CaACO}$ ) gene was expressed in the final stages of pericarp maturation, when the exocarp turned from green to red. Interestingly, highest levels of $\mathrm{CaACO}$ transcripts were detected simultaneously with the peak of ethylene emission by the fruits (Pereira et al., 2005). In comparison with other studies showing that maximum rates of respiration during fruit maturation coincide with ripening time (Puschmann, 1975; Marín-López et al., 2003), these results argue for the climacteric nature of coffee fruit ripening. Attempts to reduce the ACC oxidase expression in transgenic coffee plants employing an antisense strategy are now underway (Stiles, 2001; Ribas et al., 2001, see Pereira et al., in this issue).

In addition to $C a A C O$ expression studies, higt enzymatic activities and gene expression of pectin methylesterase (EC 3.1.1.11) and polygalacturonase (EC 3.2.1.15) have also been reported, respectively at the intermediate and final stages of pericarp maturation (Pimenta et al., 2000; Pimenta and Vilela, 2002; Cação et al., 2003; Budzinski et al., 2005). These carbohydrate-degrading enzymes should be responsible for the increase of soluble material during the maturation of the pericarp (Marín-López et al., 2003), and favor other enzymatic pathways, like sucrose synthesis detected in later pericarp development (figure 7B).

Electronic expression profile: Generally, the frequency of EST correlates with transcript accumulation in the tissues from which the cDNA library originated. In table 1, we presented the number of ESTs found in cDNA libraries of the Brazilian Coffee Genome Project for some cDNAs already cloned and discussed above.

ESTs for most of the cDNA sequences coding for enzymes of sugar metabolism were encountered in fruit cDNA libraries (FR), with a higher proportion of ESTs homologous to the CaSUS1 cDNA compared to those homologous to CaINV1 and CaVAC1 partial cDNA sequences, coding for cell-wall and acid vacuolar invertases respectively (Marraccini et al., 2003 b,c). It is interesting to note that many CaSUS1 ESTs are also detected in the cDNA libraries from in vitro tissues (CA, CB, EA), which again argues for a sucrose-degrading function of the CaSUS1 protein isoform of SUS. The low amount of ESTs homologous to the CaSUS2 cDNA in the FR cDNA libraries is curious, since it was expected to be higher according to expression analysis performed by Northern-blot experiments (figure 8A). The under-representation of cDNA from latest stages of fruit development within the cDNA 
libraries of the Coffee Genome Project could be explained by the difficulty to extract mRNA of high molecular weight and so be amenable for correct reverse transcription from carbohydrate-rich tissues. As expected, a large number of ESTs homologous to the CaRBCS1 cDNA encoding for the small subunit of the ribulose-1,5-bisphosphate carboxylase (Marraccini et al., 2003a) were found not only in cDNA libraries from photosynthetic tissues, like leaves (AR, LV, $\mathrm{RM}, \mathrm{SH}$ ) and flower buds (FB), but also in those of whole cherries of $C$. canephora at the early developmental stage, where it is probably due to $r b c S$ expression in the pericarp (Lin et al., 2005).

ESTs homologous to cDNA sequences coding for enzymes of the CGA pathway (PAL, C4H, C3H and 4CL) are found in fruits cDNA libraries, confirming previous expression analysis performed by RT-PCR experiments (see section "Gene expression during coffee fruit developmentgenes of sucrose metabolism"). As expected, a high amount of PAL-encoding ESTs are also present in cDNA libraries from photosynthetic tissues. However no ESTs homologous to the CaHCT1 full-length cDNA were encountered, suggesting the implication of other HCT-encoding genes in the synthesis of CGA compounds in fruits.

The large number of EST homologous to the CaCSP1 encountered in seed cDNA libraries (table 1, Lin et al., 2005) confirmed the fruit-specific expression of this gene (figure 8). EST sequences homologous to the partial cDNA AR-52 cDNA (hereafter renamed $\mathrm{CaCHI1),} \mathrm{were} \mathrm{also} \mathrm{strongly}$ detected in fruit (FR) cDNA libraries, as well as in flower buds (FB), branches infected by Xylella fastidiosa (RX), and in water-stressed coffee plants ( $\mathrm{SH})$. Large numbers of CaCHIl EST sequences were also found in coffee plants field-cultivated under irrigation (SS) and in plantlets treated with arachidonic acid (LP). Because arachidonic acid functions as a chemical elicitor capable of inducing the expression of pathogenesis-related genes (Marineau et al., 1987), this suggests that the CaCHIl chitinase is involved in defense mechanisms against pathogen attacks. On the other hand, EST sequences homologous to the CaCHI2 cDNA, encoding for the class-III chitinases highly expressed in the perisperm (figure 3), were also mainly detected in FR and FB cDNA libraries, but undetectable in SS and LP libraries. This argues for the participation of this type of chitinase in morphogenesis processes, as described previously.

In $C$. canephora, Lin et al. (2005) also observed the presence of a chitinase unigene (\# 120685, hereafter renamed $\mathrm{CcCHI3)}$, formed by the clusterization of 204 ESTs preferentially expressed at earlier stages of cherry development. Its putative protein differs from the partial $\mathrm{CaCHI} 1$ (52\% identity, $69 \%$ homology) and entire CaCHI2 (44\% identity, $56 \%$ homology) proteins. Searches in databases revealed that the $\mathrm{CcCHI} 3$ protein was similar to the translation product of the mRNA clone MN-SSH1-A01 from C. arabica var. Mundo Novo IAC 388-17-1, isolated from leaves infected by Hemileia vastatrix (Guzzo et al., 2005). In the Coffee Genome Project, 1122 ESTs homologous to the unigene $\mathrm{CcCHI3}$ were encountered, mainly in FR and in FB cDNA libraries, but also in leaves treated (AR) or not (LV) with arachidonic acid, a situation that was not observed for CaCHI2 (table 1). Overall, this electronic Northern shows that coffee plants contain several classes of chitinases differentially expressed in tissues, probably assuming distinct biological functions.

With regard to proteases, ESTs coding for aspartic protease were the most abundant, particularly in fruits, although they were detected in all cDNA libraries. For the caffeine pathway, ESTs homologous to 7-methylxanthosine synthase (CmXRS1), theobromine synthase (CTS1) and caffeine synthase $(C C S 1)$ were present in cDNA libraries from fruits (FR) as well as flower buds (FB) and leaf tissues (LV), confirming expression analyses performed by RT-PCR by others (Ogawa et al., 2001; Mizuno et al., 2003a, 2003b; Uefuji et al., 2003). Interestingly, the ESTs coding for these enzymes were not over-expressed in cDNA libraries from plants submitted to biotic (RM, RX) or abiotic (SH) stress.

Conclusions: As in other plants, the biochemical compounds accumulated in mature coffee seeds are either imported from other plant organs (leaves, pericarp) or synthesized de novo. Even if the perisperm is present transitorily during coffee fruit development, some studies have reported its importance during coffee bean development as a transfer tissue able to provide compounds (i.e. sugars, organic acids etc) to the endosperm where several enzymatic activities and expressed genes were yet reported. Most of these syntheses were observed during the endosperm expansion phase (between 12 and 24 WAF in C. arabica), except for the CaSUS2 gene, which is the unique gene characterized to date to be highly expressed during the dehydration phase occurring just before harvest. As observed by Lin et al. (2005), genes expressed in the three stages of $C$. canephora cherry development (early: 18-22 WAF; middle: $\approx 33$ WAF; late: 42-46 WAF) appeared to be very different, arguing for the existence of a continuous cascade of molecular events in developing coffee fruits. 
Together, this shows the importance of analyzing tissue interactions to have reach a better understanding of coffee fruit physiology and molecular biology.

\section{General conclusions and perspectives}

Regarding the information summarized in the present review, it is clear that the relationships existing between pericarp, perisperm and endosperm tissues during coffee fruit development are crucial for the elaboration of final characteristics of coffee beans. If some biochemical pathways are now quite well elucidated, as in the case for caffeine, others are still devoid of data, either from the biochemical or molecular point of view. One way to elucidate these pathways would be to focus on genes coding for pathway enzymes, like those expressed during the germination process for example. Some studies have already reported the existence of carbohydrate-degrading enzymes, like endo- $\beta$ mannanases and $\alpha$-D-galactosidase (Giorgini and Campos, 1992; Marraccini et al., 2001b; Marraccini et al., 2005), and trigonelline demethylase (Shimizu and Mazzafera, 2000) specifically activated and/or expressed during coffee bean germination. Because coffee seeds submitted either to wet or dry processes have an active metabolism (Bytof et al., 2005), more attention should also be given to the analysis of enzymes activated or specifically expressed during post-harvest treatments. For example, it might be of particular interest to investigate the origin of free amino acids increasing in wet processed beans, as this is one of the events suspected to explain the better cup quality of wet-processed coffee compared to dry-processed coffee (Bytof et al., 2000; Selmar et al. 2001). The large number of EST sequences generated by the Brazilian Coffee Genome Project will now permit the identification and characterization of genes activated or repressed during these different treatments, like those of proteases and sugars (polysaccharide)-degrading enzymes. Another important aspect concerns the use of EST sequences to analyze the genetic diversity within the Coffea genus, particularly to identify the genes affected in natural coffee mutants, i.e. Moka, Maragogipe (Krug, 1949).

Recent information about coffee plant development and adaptation to environmental factors has also revealed that seed physiology and development could vary depending on the position of the fruits within plagiotropic branches and the light they received (Vaast et al., 2002, 2006), suggesting that the biochemistry and gene expression could be different within the fruits on the same plant. A better knowledge of such relationships should be very helpful particularly to elucidate the effects of environmental parameters on coffee beverage quality.

Acknowledgments: We are grateful to Wagner Thompson Estanislau (Universidade Federal de Lavras - UFLA, Lavras, Minas Gerais, Brazil) for all documents relative to his MSc dissertation, Sandra Maria Carmelo Guerreiro (Universidade de Campinas - UNICAMP - Departamento de Botânica, São Paulo, Brazil) and Clara Geromel (Universidade de Campinas - UNICAMP - Departamento de Fisiologia Vegetal, Campinas, São Paulo, Brazil) for the work on histological cuts and enzyme assays. We would like also to thank Elisabeth Keiko Takahashi for her help on computer analysis of the Brazilian Coffee Genome Project, Prof. Paulo Mazzafera (Universidade de Campinas - UNICAMP - Departamento de Fisiologia Vegetal, Campinas, São Paulo, Brazil) and Dr. Luiz Gonzaga Esteves Vieira (Instituto Agronômico do Paraná - IAPAR - Laboratório de Biotecnologia Vegetal, Londrina, Paraná, Brazil) for their critical reading of the manuscript. The access to the Coffee Genome Project (www.lge.ibi.unicamp.br/cafe/) to Pierre Marraccini was registered by the contract of scientific collaboration "Plant Breeding for Coffee Quality" signed between IAPAR and CIRAD (2002-2008). PM received the financial support of the French Embassy in Brazil (project DCSUR-BRE-4C5-008).

\section{REFERENCES}

Acuña R, Bassüner R, Beillinson V, Cortina H, Cadena-Gómez G, Montes V, Nielsen NC (1999) Coffee seeds contain 11S storage proteins. Physiol. Plant. 105: 122-131.

Aerts RJ, Baumann TW (1994) Distribution and utilization of chlorogenic acid in Coffea seedlings. J. Exp. Bot. 45: 497-503.

Altschul SF, Madden TL, Schäffer AA, Zhang J, Zhang Z, Miller W, Lipman DJ (1997) Gapped BLAST and PSI-BLAST: a new generation of protein database search programs. Nucleic Acids Res. 25: 3389-3402.

Amorim HV, Silva DM (1968) Relationship between the polyphenol oxidase activity of the coffee beans and the quality of the beverage. Nature 219: 381-382.

Amorim HV, Teixeira AA, Melo M, Cruz VF, Malavolta E (1975) Chemistry of Brazilian green coffee and quality of the beverage. IV. Electrophoresis of soluble proteins in agar-gel and its interaction with chlorogenic acids. Turrialba 25: 18-25.

Amorim HV, Amorim VL (1977) Coffee enzymes and coffee quality. In: Ory RL and St Angelo AJ (Eds) Enzymes in food and beverages processing, ACS Symposium Series, 47, American Chemical Society, pp. 27-56.

Arnold U, Ludwig E, Kühn R, Möschwitzer U (1994) Analysis of free amino acids in green coffee bean. I. Determination of amino acids after precolumn derivatization using 
9-fluorenylmethylchloroformate. Z. Lebensm. Unters Forsch 1999: 22-25.

Arnold U, Ludwig E (1996) Analysis of free amino acids in green coffee bean. II. Changes of the amino acid content in arabica coffees in connection with post-harvest model treatment. Z. Lebensm. Unters Forsch 203: 379-384.

Ashihara H, Monteiro AM, Gillies FM, Crozier A (1996) Biosynthesis of caffeine in leaves of coffee. Plant Physiol. 111: 747-753.

Ashihara H, Crozier A (2001) Caffeine: a well known but little mentioned compound in plant science. Trends Plant Sci. 6: 407-413.

Avallone S (1999) Etude de la fermentation naturelle de Coffea arabica $\mathrm{L}$. et des mécanismes de fluidification du tissu mucilagineux. Montpellier II University, France. PhD Thesis.

Baptista GG, Mazzafera P, Priolli RHG, Shimizu MM, Schocken NRL, Colombo C (2005) Identificação e caracterização de ESTs presentes no banco do genoma café relacionados a proteases. IV Simpósio de Pesquisa dos Cafés do Brasil, Londrina (PR), CD-rom.

Baskin TI, Busby CH, Fowke LC, Sammut M, Gubler F (1992) Improvements in immunostaining samples embedded in methacrylate: localization of microtubules and other antigens throughout developing organs in plants of diverse taxa. Planta 187: 405-413.

Bättig K (1985) The physiological effects of coffee consumption. In: Clifford MN and Wilson KC (Eds) Coffee: botany, biochemistry and production of beans and beverage, pp.394-439. Croom Helm, London.

Baú SMT, Mazzafera P, Santoro LG (2001) Seed storage proteins in coffee. Rev. Bras. Fisiol. Veg. 13:33-40.

Baumann TW, Wanner H (1972) Untersuchungen über den transport von kaffein in der kaffeepflanze Coffea arabica. Planta 108: 11-20.

Baumann TW, Mösli S-S, Schulthess BH, Aerts RJ (1993) Interdependence of caffeine and chlorogenic acid (5-CQA) metabolism in coffee. Proceedings of the $15^{\text {th }}$ International Scientific Colloquium on Coffee, Lomé, International Scientific Association on Coffee, Paris, pp.134-140.

Begnami CN, Cortelazzo AL, Mazzafera P, Dolder MAH (1999) Structural and biochemical alterations during the loss of viability of seeds of Coffea arabica cv. Catuaí Vermelho. Acta Microscopica 8: 803-814.

Beille L (1947) Anatomie comparative du genre Coffea et de quelques Rubiacées-Ixorées. In: Les caféiers du globe, Le Chevalier (Eds), Paris, pp.23-81.

Ben Amor M, Denis V, McCarthy J (2003) Molecular cloning and characterization of cDNAs encoding three different proteases in Coffea canephora. Proc. $7^{\text {th }}$ International Symposium of Plant Molecular Biology ISPMB. Poster S03-57, Barcelona (Spain).

Berthaud J (1980) L'incompatibilité chez Coffea canepho$r a$ : méthode de test et déterminisme génétique. Café Cacao Thé 24:267-274.

Bertrand C, Noirot M, Doulbeau S, de Kochko A, Hamon S, Campa C (2003) Chlorogenic acid content swap during fruit maturation in Coffea pseudozanguebariae. Qualitative comparison with leaves. Plant Sci. 165:1355-1361.

Bouchet S, Marraccini P, Jourdan I, Leroy T, Vieira LGE, Ferreira LP, Musoli P, Pot D (2005) Nucleotide diversity and molecular evolution of five genes involved in the sucrose biosynthesis pathway of Coffea canephora. In: Proc. $4^{\text {th }}$ Plant Genomics European Meeting, Amsterdam.

Budzinski IGF, Cação SMB, Carneiro CEA, Pereira LFP, Vieira LGE (2005) Análise de genes expressos durante estádios finais da maturação de frutos de café. IV Simpósio de Pesquisa dos Cafés do Brasil, Londrina (PR), CD-rom.

Bytof G, Selmar D, Schieberle P (2000) New aspects of coffee processing: how do the different post harvest treatments influence the formation of potential flavour precursors? J. Appl. Bot. 74:131-136.

Bytof G, Knopp SE, Schieberle P, Teutsch I, Selmar D (2005) Influence of processing on the generation of $\gamma$-aminobutyric acid in green coffee beans. Eur. Food Res. Technol. 220:245-250.

Cação SMB, Galvão RM, Pereira LFP, Vieira LGE (2003) Identificação e caracterização de genes de poligalacturonase de Coffea arabica. III Simpósio de Pesquisa dos Cafés do Brasil, Porto Seguro (BA), pp.98-99.

Campa C, Noirot M, Bourgeois M, Pervent M, Ky CL, Chrestin H, Hamon S, de Kochko A (2003) Genetic mapping of a caffeoyl-coenzyme A 3-O-methyltransferase gene in coffee trees. Impact on chlorogenic acid content. Theor. Appl. Genet. 107:751-756.

Campa C, Ballester JF, Doulbeau S, Dussert S, Hamon S, Noirot M (2004) Trigonelline and sucrose diversity in wild Coffea species. Food Chem. 88: 39-44.

Campa C, Venkataramaiah M, de Kochko A, Le Gal L, Bourgeois M, Moreau C, Hamon S, Noirot M (2005) Candidate gene strategy for the study of the chlorogenic acid biosynthesis. Proceedings of the $20^{\text {th }}$ International Scientific Colloquium on Coffee, Bangalore, International Scientific Association on Coffee, Paris, pp.644-650.

Cannell MRG (1971) Production and distribution of dry matter in trees of Coffea arabica L. in Kenya as affected by seasonal climatic differences and the presence of fruit. Ann. Appl. Biol. 67:99-120.

Cannell MRG (1985) Physiology of the coffee crop. In: Clifford MN and Wilson KC (Eds) Coffee: botany, biochemistry and production of beans and beverage, Croom Helm, London, pp 108-134.

Carchon H, De Bruyne CK (1975) Purification and properties of coffee bean $\alpha$-D-galactosidase. Carbohydr. Res. 41: 175-189.

Carvalho A, Antunes Filho H, Mendes JET, Lazzarini W, Reis AJ, Aloisi Sobrinho J, Moraes MV, Nogueira RK, Rocha TR (1957) Melhoramento do cafeeiro: XIII. Café Bourbon Amarelo. Bragantia 16: 411-455.

Casal S, Oliveira MBPP, Alves MR, Ferreira MA (2001) Characterization of free amino acid enantiomers of Arabica and Robusta coffee varieties. Proceedings of the $19^{\text {th }}$ International Scientific Colloquium on Coffee, Trieste, International Scientific Association on Coffee, Paris, CD-ROM-C320. 
Cavin C, Holzhaüser D, Constable A, Hugget AC, Schilter B (1998) The coffee-specific diterpenes cafestol and kahweol against aflatoxin B1-induced genetoxicity through a dual mechanism. Carcinogenesis 19: 1369-1375.

Charrier A, Berthaud J (1985) Botanical classification of coffee. In: Clifford MN and Willson KC (Eds) Coffee: Botany, biochemistry and production of beans and beverage, pp.13-47. Croom Helm, London.

Cilliers JJL, Singleton VL (1991) Characterization of the products of nonenzymic autoxidative phenolic reactions in a caffeic acid model system. J. Agric. Food Chem. 39: 1298-1303.

Clendennen SK, Lopez-Gomez R, Gomez Lim M, Arntzen CJ, May GD (1998) The abundant 31kDa banana pulp protein is homologous to class III acidic chitinases. Phytochemistry 47: 613-619.

Clifford MN (1985a) Chemical and physical aspects of green coffee and coffee products. In: Clifford $\mathrm{MN}$ and Wilson $\mathrm{KC}$ (Eds) Coffee: botany, biochemistry and production of beans and beverage, pp.305-375. Croom Helm, London.

Clifford MN (1985b) Chlorogenic acids. In: Clarke RJ and Macrae R (Eds) Coffee. Vol. 1: Chemistry, pp.153-202. Elsevier Appl. Sci Publ., London.

Courtois JE, Petek F (1966) $\alpha$-Galactosidase from coffee beans. Meth. Enzymol. 8: 565-571.

Crisosto CH, Grantz DA, Osgood RV, Luza JG (1990) Effect of ethephon application on the fruit removal force and abscission zone formation of Coffea arabica $L$. varieties Proceedings of the $17^{\text {th }}$ Plant Growth Regulator Society of America, Annual Meeting, pp.27-35.

Crisosto CH, Grantz DA, Osgood RV, Cid LR (1992) Synchronization of fruit ripening in coffee with low concentrations of ethephon. Postharvest Biol. Tech. 1: 371-378.

Daglia M, Racchi M, Papetti A, Lanni C, Govoni S, Gazzani $\mathrm{G}$ (2004) In vitro and ex vivo antihydroxyl radical activity of green and roasted coffee. J. Agric. Food Chem. 52: 1700-1704.

De Castro RD (1998) Functional analysis of cell cycle events in developing and germinating tomato seeds. Wageningen University, Netherlands. PhD Thesis,

De Castro RD, Hilhorst HWM (2000) Dormancy, germination and the cell cycle in developing and imbibing tomato seeds. Rev. Bras. Fisiol. Veg. 12: 105-136.

De Castro RD, Van Lammeren AAM, Groot SPC, Bino RJ, Hilhorst HWM (2000) Cell division and subsequent radicle protrusion in tomato seeds are inhibited by osmotic stress but DNA synthesis and formation of microtubular cytoskeleton are not. Plant Physiol. 122: 1-9.

De Castro RD, Estanislau WT, Mesquita PR, Hilhorst HWM (2001) A semente de café: desenvolvimento e perspectivas genômicas. II Simpósio de Pesquisa dos Cafés do Brasil, Vitória (ES), pp.253-260.

De Castro RD, Estanislau WT, Carvalho MLM, Hilhorst HWM (2005) Functional development and maturation of coffee (Coffea arabica) fruits and seeds. Proceedings of the $20^{\text {th }}$ International Scientific Colloquium on Coffee, Bangalore, International Scientific Association on Coffee, Paris, pp.619-635.
De Jong AJ, Cordewener J, Lo Schiavo F, Terzi M, Vandekerkhove J, Van Kammen A, De Vries SC (1992) A carrot somatic embryo mutant is rescued by chitinase. Plant Cell 4: 425-433.

De Maria CAB, Trugo LC, Moreira RFA, Werneck CC (1994) Composition of green coffee fractions and their contribution to the volatile profile formed during roasting. Food Chem. 50: 141-145.

De Maria CAB, Trugo LC, Aquino Neto FR, Moreira RFA, Alviano CS (1996) Composition of green coffee water-soluble fractions and identification of volatiles formed during roasting Food Chem. 55: 203-207.

De Melo Ayres GC (1954) A ocorrência de plasmodesmas no endosperma de Coffea arabica L. var Typica Cramer. Bragantia 13: 281-286.

De Roos B, van der Weg G, Urgert R, van den Bovenkamp P, Charrier A, Katan MB (1997) Levels of cafestol, kahweol, and related diterpenoids in wild species of the coffee plant Coffea. J. Agric. Food Chem. 45: 3065-3069.

De Roos B, Caslake MJ, StalenhoefAFH, Bedford D, Demacker PNM, Katan MB, Packard CJ (2001) The coffee diterpene cafestol increase plasma triacylglycerol by increasing the production rate of large VLDL apolipoprotein B in healthy normolipidemic subjects. Am. J. Clin. Nutr. 73: 45-52.

Decazy F, Avelino J, Guyot B, Perriot JJ, Pineda C, Cilas C (2003) Quality of different Honduras coffees in relation to several environments. J. Food Sci. 68: 2356-2361

Dedecca DM (1957) Anatomia e desenvolvimento ontogenético de Coffea arabica L. var. Typica Cramer. Bragantia 16: 315-355.

Dentan E (1985a) The microscopy structure of the coffee bean. In: Clifford MN and Wilson KC (Eds) Coffee: botany, biochemistry and production of beans and beverage, pp.284304. Croom Helm, London.

Dentan E (1985b) Etude microscopique du développement et de la maturation du grain de café. Proceedings of the $11^{\text {th }}$ International Scientific Colloquium on Coffee, Lomé, International Scientific Association on Coffee, Paris, pp.381-398.

Estanislau WT (2002) Modelo funcional de desenvolvimento de sementes de cafeeiro (Coffea arabica L.). Lavras Federal University (UFLA) MG, Brazil. MSc Thesis.

Frischknecht PM, Ulmer-Dufek J, Baumann TW (1986) Purine alkaloid formation in buds and developing leaflets of Coffea arabica: expression of an optimal defense strategy? Phytochemistry 25: 613-616.

Gaborit C, Caillet V, Deshayes A, Marraccini P (2003) Molecular cloning of a full-length cDNA and gene from Coffea arabica encoding a protein homologous to the yeast translation initiation factor SUI1: expression analysis in plant organs. Braz. J. Plant Physiol. 15: 55-58.

Galvão RM, Kobayashi AK, Ribas AF, Bespalhok Filho JC, Pereira LFP, Vieira LGE (2001) Identificação e caracterização de genes de ACC oxidase de café. II Simpósio de Pesquisa dos Cafés do Brasil, Vitória (ES), pp.375-381.

Geromel C (2002) Atividade hidrolítica da sacarose associada ao desenvolvimento do fruto de cafeeiro. Lavras Federal University (UFLA) MG, Brazil. MSc Thesis. 
Geromel C, Ferreira LP, Cavalari AA, Pereira LFP, Guerreiro SMC, Vieira LGE, Leroy T, Mazzafera P, Marraccini P (2005) Sugar metabolism during coffee fruit development. Proceedings of the $20^{\text {th }}$ International Scientific Colloquium on Coffee, Bangalore, International Scientific Association on Coffee, Paris, pp.651-655.

Geromel C, Ferreira LP, Cavalari AA, Pereira LFP, Guerreiro SMC, Vieira LGE, Leroy T, Pot D, Mazzafera P, Marraccini $\mathrm{P}$. Analysis of sucrose synthase genes during coffee (Coffea arabica) fruit development. Submitted.

Gerrits PO, Smid L (1983) A new, less toxic polymerization system for the embedding of soft tissues in glycol methacrylate and subsequent preparing of serial sections. J. Microsc. 132: 81-85.

Gillies FM, Jenkins GI, Ashihara H, Crozier A (1995) In vitro biosynthesis of caffeine: the stability of $N$-methyltransferase activity in cell-free preparations from liquid endosperm of Coffea arabica. Proceedings of the $16^{\text {th }}$ International Scientific Colloquium on Coffee, Kyoto, International Scientific Association on Coffee, Paris, pp.599-605.

Ginz M, Balzer HH, Bradbury AGW, Maier HG (2000) Formation of aliphatic acids by carbohydrate degradation during roasting of coffee. Eur. Food Res. Technol. 211: 404-410.

Giorgini JF, Campos CASP (1992) Changes in the content of soluble sugars and starch synthesis and degradation during germination and seedling growth of Coffea arabica L. Rev. Bras. Fisiol. Veg. 4: 11-15.

Golden KD, John MA, Kean EA (1993) $\beta$-galactosidase from Coffea arabica and its role in fruit ripening, Phytochemistry $34: 355-360$.

Gough C (2003) Rhizobium symbiosis: insight into Nod factor receptor. Curr Biol 13: R973-R975.

Graham LS, Sticklen MB (1994) Plant chitinases. Can. J. Bot. 72: 1057-1083.

Grosch W (2001) Volatile compounds. In: Clarke RJ and Vitzthum OG (Eds) Coffee: recent developments, pp.68-89. Blackwell Science, Oxford.

Guyot B, Petnga E, Vincent JC (1988) Analyse qualitative d'un café Coffea canephora var. Robusta en fonction de la maturité. I. Evolution des caractéristiques physiques, chimiques et organoleptiques. Café Cacao Thé 32: 127-130.

Guyot B, Gueule D, Manez JC, Perriot JJ, Giron J, Villain L (1996) Influence de l'altitude et de l'ombrage des cafés Arabica. Plantat. Recher. Dév. 3: 272-280.

Guzzo SD, Harakava R, Tsai SM (2005) Coffee genes expressed during systemic acquired resistance and incompatible interaction with Hemileia vastatrix. GenBank accession number DQ124036.

Haibach F, Hata J, Mitra M, Dhar M, Harmata M, Sun P, Smith D (1991) Purification and characterization of a Coffea canephora $\alpha$-D-galactosidase isozyme. Biochem. Biophys. Res. Commun. 181: 1564-1571.

Hoffmann L, Maury S, Martz F, Geoffroy P, Legrand M (2003) Purification, cloning, and properties of an acyltransferase controlling shikimate and quinate ester intermediates in phenylpropanoid metabolism. J. Biol. Chem. 278: 95-103.
Homma S (2001) Non-volatile compounds, part II. In: Clarke RJ and Vitzthum OG (Eds) Coffee: recent developments, pp.50-67. Blackwell Science, Oxford.

Houk WG (1936) The ovule and seed of Coffea arabica L. Science 83: 464-465.

Houk WG (1938) Endosperm and perisperm of coffee with notes on the morphology of the ovule and seed development. Am. J. Bot. 25: 56-61.

Jing HC, Van Lammeren AAM, De Castro RD, Hilhorst HWM, Bino RJ, Groot SPC (1999) B-Tubulin accumulation and DNA synthesis are sequentially resumed in embryo organs of cucumber Cucumis sativus L. seeds during germination. Protoplasma 208: 230-239.

Jing HC, Bergervoet JHW, Jalink H, Klooster M, Du SL, Bino RJ, Hilhorst HWM, Groot SPC (2000) Cucumber (Cucumis sativus L.) seed performance as influenced by ovary and ovule position. Seed Sci. Res. 10: 435-445.

Keller H, Wanner H, Baumann TW (1971) Koffein-synthese und gewebekultur bei Coffea arabica. Verhandl Schweiz. Naturforsch. Ges: 88-90.

Keller H, Wanner H, Baumann TW (1972) Kaffein-synthese in fruchten und gewebekulturen von Coffea arabica. Planta 108: 339-350.

Kölling-Speer I, Speer K (1997) Diterpenes in coffee leaves. Proceedings of the $17^{\text {th }}$ International Scientific Colloquium on Coffee, Nairobi, International Scientific Association on Coffee, Paris, pp.150-154.

Kumar D, Tieszen LT (1976) Some aspects of photosynthesis and related processes in Coffea arabica L. Kenya Coffee 41: 309-315.

Krug CA (1949) Mutação em Coffea arabica L. Bragantia 9: 1-10.

Ky CL, Louarn J, Dussert S, Guyot B, Hamon S, Noirot M (2001a) Caffeine, trigonelline, chlorogenic acids and sucrose diversity in wild Coffea arabica L. and C. canephora P. accessions. Food Chem. 75: 223-230.

Ky CL, Guyot B, Louarn J, Hamon S, Noirot M (2001b) Trigonelline inheritance in the interspecific Coffea pseudozanguebariae x $C$. liberica var. dewevrei cross Theor. Appl. Genet. 102: 630-634.

Lam LK, Sparnins VL, Wattenberg LW (1982) Isolation and identification of kahweol palmitate and cafestol palmitate as active constituents of green coffee beans that enhance glutathione $S$-transferase activity in mouse. Cancer Res. 42: 1193-1198.

Lashermes P, Combes MC, Robert J, Trouslot P, D’Hont A, Anthony F, Charrier A (1999) Molecular characterisation and origin of the Coffea arabica L. genome. Mol. Gen. Genet. 261: 259-266.

Lashermes P, Paczek V, Trouslot P, Combes MC, Couturon E, Charrier A (2000) Single-locus inheritance in the allotetrapoid Coffea arabica L. and interspecific hybrid $C$. arabica x C. canephora. J. Hered. 91: 81-85.

Lawton KA, Beck J, Potter S, Ward E, Ryals J (1994) Regulation of cucumber class III chitinase gene expression. Mol. Plant-Microbe Interact. 7: 48-57.

Leloup V, Louvrier A, Liardon R (1995) Degradation mecan- 
isms of chlorogenic acids during roasting. Proceedings of the $16^{\text {th }}$ International Scientific Colloquium on Coffee, Kyoto, International Scientific Association on Coffee, Paris, pp.192-198.

Leroy T, Marraccini P, Dufour M, Montagnon C, Lashermes P, Sabau X, Ferreira LP, Jourdan I, Pot D, Andrade AC, Glaszmann JC, Vieira LGE, Piffanelli P (2005) Construction and characterization of a Coffea canephora BAC library to study the organization of sucrose biosynthesis genes. Theor. Appl. Genet. 111: 1032-1041.

Lin C, Mueller LA, Mc Carthy J, Crouzillat D, Pétiard V, Tanksley S (2005) Coffee and tomato share common gene repertoires as revealed by deep sequencing of seed and cherry transcripts. Theor. Appl. Genet. 112: 114-130.

Liu Y, Wang H, Ye HC, Li GF (2005) Advances in the plant isoprenoid biosynthesis pathway and its metabolic engineering. J. Integ. Plant Biol. 47: 769-782.

Ludwig E, Arnold U (1996) Analysis of free amino acids in green coffee beans. II. Changes of the amino acid content in Arabica coffees in connection with post-harvest model treatment. Z. Lebensm. Unters Forsch. 203: 379-384.

Ludwig E, Lipke U, Raczek U, Jäger A (2000) Investigations of peptides and proteases in green coffee beans. Eur. Food Res. Technol. 211: 111-116.

Maillard LC (1912) Action des acides aminés sur les sucres: formation des mélanoïdines par voie méthodique. Compt. R. Acad. Sci. Paris 154: 66-68.

Marín-López SM, Arcila-Pulgarin J, Montoya-Restrepo EC, Olivero-Tascón CE (2003) Cambios físicos y químicos durante la maduración del fruto de café (Coffea arabica L. var. Colombia). Cenicafé 54: 208-225.

Marineau C, Matton DP, Brisson N (1987) Differential accumulation of potato tuber mRNAs during the hypersensitive response induced by arachidonic acid elicitor. Plant Mol. Biol. 9: 335-342.

Marraccini P, Deshayes A, Pétiard V, Rogers WJ (1999) Molecular cloning of the complete $11 \mathrm{~S}$ seed storage protein gene of Coffea arabica and promoter analysis in transgenic tobacco plants. Plant Physiol. Biochem. 37: 273-282.

Marraccini P, Allard C, André ML, Courjault C, Gaborit C, Lacoste N, Meunier A, Michaux S, Petit V, Priyono P, Rogers WJ, Deshayes A (2001a). Update on coffee biochemical compounds, protein and gene expression during bean maturation and in other tissues. Proceedings of the $19^{\text {th }}$ International Scientific Colloquium on Coffee, Trieste, International Scientific Association on Coffee, Paris, CDROM-B214.

Marraccini P, Rogers WJ, Allard C, André ML, Caillet V, Lacoste N, Lausanne F, Michaux S (2001b) Molecular and biochemical characterization of endo- $\beta$-mannanases from germinating coffee (Coffea arabica) grains. Planta 213: 296-308.

Marraccini P, Courjault C, Caillet V, Lausanne F, Lepage B, Rogers WJ, Tessereau S, Deshayes A (2003a) Rubisco small subunit of Coffea arabica: cDNA sequence, gene cloning and promoter analysis in transgenic tobacco plants. Plant Physiol. Biochem. 41: 17-25.
Marraccini P, Pereira LFP, Ferreira LP, Vieira LGE, Geromel C, Cavalari AA, Mazzafera P, Leroy T (2003b) Coffea arabica partial mRNA for cell-wall invertase. GenBank accession number AJ575257.

Marraccini P, Pereira LFP, Ferreira LP, Vieira LGE, Geromel C, Cavalari AA, Mazzafera P, Leroy T (2003c) Coffea arabica partial mRNA for acid vacuolar invertase. GenBank accession number AJ575258.

Marraccini P, Rogers WJ, Caillet V, Deshayes A, Granato D, Lausanne F, Lechat S, Pridmore D, Pétiard V (2005) Biochemical and molecular characterization of $\alpha$-D-galactosidase from coffee beans. Plant Physiol. Biochem. 43: 909-920.

Marshall CF (1985) World coffee trade. In: Clifford MN and Wilson KC (Eds) Coffee: botany, biochemistry and production of beans and beverage, pp.251-283. Croom Helm, London.

Mason HS (1955) Reactions between quinones and proteins. Nature 175: 771-772.

Mazzafera P (1991) Trigonelline in coffee. Phytochemistry 30: 2309-2310.

Mazzafera P, Crozier A, Sandberg G (1994) Studies on the metabolic control of caffeine turnover in developing endosperms and leaves of Coffea arabica and C. dewevrei. J. Agric. Food Chem. 42: 1423-1427.

Mazzafera P, Soave D, Zullo MAT, Guerreiro Filho O (1998) Oil content of green beans from some coffee species. Bragantia 57: 45-48.

Mazzafera P, Gonçalves KV (1999) Nitrogen compounds in the xylem sap of coffee. Phytochemistry 50: 383-386.

Mazzafera P, Robinson SP (2000) Characterization of polyphenol oxidase in coffee. Phytochemistry 55: 285-296.

Medina DM (1964) O endosperma de café como material para estudos citológicos. Bragantia 23: 179-186.

Medina DM (1965) Novas observações citológicas no endosperma de café. Bragantia 24: 369-384.

Melo M, Amorim HV (1975) Chemistry of Brazilian green coffee and quality of the beverage. VI. U.V and visible spectral analysis and chlorogenic acids content on TCA soluble buffer extracts. Turrialba 25: 243-248.

Melo GA (2005) Purificação da enzima polifenoloxidase do cafeeiro, sua relação com resistência a pragas e controle da síntese de seu principal substrato, o acido chlorogênico. Campinas University (UNICAMP) SP, Brazil. PhD Thesis.

Melo GA, Mazzafera P (2005) Control of chlorogenic acid formation in leaves and endosperm of Coffea arabica coffee fruits. Proceedings of the $20^{\text {th }}$ International Scientific Colloquium on Coffee, Bangalore, International Scientific Association on Coffee, Paris, pp.775-778.

Mendes AJT (1941) Cytological observations in Coffea VI. Embryo and endosperm development in Coffea arabica L. Am. J. Bot. 28: 784-789.

Mendes AJT (1942) Desenvolvimento do embrião e do endosperma em Coffea arabica L. Bragantia 2: 115-128.

Menezes JBF, Maneiro ALS (1955) Sobre a estructura microscopica do fruto do café. Boletim da Superintendência dos Serviços do Café. 335: 19-37. 
Mizuno K, Okuda A, Kato M, Yoneyama N, Tanaka H, Ashihara $\mathrm{H}$ (2003a) Isolation of a new dual-functional caffeine synthase gene encoding an enzyme for the conversion of 7-methylxanthine to caffeine from coffee (Coffea arabica L.). FEBS Lett. 534: 75-81.

Mizuno K, Kato M, Irino F, Yoneyama N, Fujimura T, Ashihara $\mathrm{H}$ (2003b) The first committed step reaction of caffeine biosynthesis: 7-methylxanthosine synthase is closely homologous to caffeine synthases in coffee (Coffea arabica L.). FEBS Lett. 547: 56-60.

Moisyadi S, Neupane KR, Stiles JI (1998) Cloning and characterization of a cDNA encoding xanthosine- $\mathrm{N}^{7}$-methyltransferase from coffee (Coffea arabica). Acta Hortic. 461: 367-377.

Moisyadi S, Neupane KR, Stiles JI (1999) Cloning and characterization of xanthosine-N7-methyltransferase, the first enzyme of the caffeine biosynthetic pathway. Proceedings of the $18^{\text {th }}$ International Scientific Colloquium on Coffee, Helsinki, International Scientific Association on Coffee, Paris, pp.327-331.

Montagnon C (2000) Optimisation des gains génétiques dans le schéma de sélection récurrente réciproque de Coffea canephora Pierre. ENSA Montpellier, France. PhD Thesis.

Montavon P, Duruz E, Rumo G, Pratz G (2003) Evolution of green protein profiles with maturation and relationship to coffee cup quality. J. Agric. Food Chem. 51: 2328-2334.

Mösli-Waldhauser SS, Baumann TW (1996) Compartmentation of caffeine and related purine alkaloids depends exclusively on the physical chemistry of their vacuolar complex formation with chlorogenic acids. Phytochemistry 42: 985-996.

Muschler R (2001) Shade improves coffee quality in sub-optimal coffee zone of Costa Rica. Agroforest Syst. 51: 131139.

Neupane KR, Moisyadi S, Stiles JI (1999) Cloning and characterization of fruit-expressed ACC synthase and ACC oxidase from coffee. Proceedings of the $18^{\text {th }}$ International Scientific Colloquium on Coffee, Helsinki, International Scientific Association on Coffee, Paris, pp.322-326.

Niggeweg R, Michael AJ, Martin C (2004) Engineering plant with increased levels of antioxidant chlorogenic acid. Nat. Biotechnol. 22: 746-754.

Ogawa M, Herai Y, Koizumi N, Kusano T, Sano H (2001) 7methylxanthine methyltransferase of coffee plants. J. Biol. Chem. 276: 8213-8218.

Ogita S, Uefuji H, Yamaguchi Y, Koizumi N, Sano H (2003) Producing decaffeinated coffee plants. Nature 423: 823.

Ogita S, Uefuji H, Morimoto M, Sano H (2004) Application of RNAi to confirm theobromine as the major intermediate for caffeine biosynthesis in coffee plants with potential for construction of decaffeinated varieties. Plant Mol. Biol. 54: 931-941.

Ouguerram A (1999) Contribution à l'étude des parois cellulaires de deux fruits inductriels: l'olive et le café. Paris VI University, France. PhD Thesis.

Pereira LFP, Galvão RM, Kobayashi AK, Cação SMB, Vieira LGE (2005) Ethylene production and ACC oxidase gene expression during fruit ripening of Coffea arabica L. Braz. J. Plant Physiol. 17: 283-289.

Peumans WJ, Proost P, Swennen RL Van Damme EJM (2002) The abundant class III chitinase homolog in young developing banana fruits behaves as a transient vegetative storage proteins and most probably serves as an important supply of amino acids for the synthesis of ripening-associated proteins. Plant Physiol. 130: 1063-1072.

Picard H, Guyot B, Vincent JC (1984) Etude des composés stéroliques de l'huile de café Coffea canephora. Café Cacao Thé 28: 47-62.

Pimenta CJ, Chagas SJR, Costa L (2000) Pectinas e enzimas pectinolíticas em café (Coffea arabica L.) colhido em quatro estádios de maturação. Rev. Ciênc. Tecnol. 24: 10791083.

Pimenta CJ, Vilela ER (2002) Qualidade do café (Coffea arabica L.) colhido em sete épocas diferentes na região de Lavras-MG. Ciênc Agrotec, Special Edition:1481-1491

Poisson J (1977) Aspects chimiques et biologiques de la composition du café. Proceedings of the $8^{\text {th }}$ International Scientific Colloquium on Coffee, Abidjan, International Scientific Association on Coffee, Paris, pp.33-57.

Post SM, de Roos B, Vermeulen M, Afman L, Jong MC, Dahlmans VE (2000) Cafestol increases serum cholesterol levels in apolipoprotein $\mathrm{E}^{*} 3$-Leiden transgenic mice by suppression of bile acid synthesis. Arterioscler. Thromb. Vasc. Biol. 20: 155-156.

Puschmann R (1975) Características bioquímicas dos frutos do cafeeiro (Coffea arabica L.) durante a maturação. Federal University Viçosa (UFV) MG, Brazil. MSc Thesis.

Redgwell RJ, Curti D, Rogers J, Nicolas P, Fischer M (2003) Changes to the galactose/mannose ratio in galactomannans during coffee bean (Coffea arabica L.) development: implications for in vivo modification of galactomannan synthesis. Planta 217: 316-326.

Ribas AF, Kobayashi AK, Bespalhok Filho JC, Galvão RM, Pereira LFP, Vieira LGE (2001) Transformação genética de café mediada por Agrobacterium tumefaciens. II Simpósio de Pesquisa dos Cafés do Brasil, pp.420-428.

Rogers WJ, Bézard G, Deshayes A, Meyer I, Pétiard V, Marraccini P (1999a) Biochemical and molecular characterization and expression of the 11S-type storage protein from Coffea arabica endosperm. Plant Physiol. Biochem. 37: 261-272.

Rogers WJ, Michaux S, Bastin M, Bucheli P (1999b) Changes to the content of sugars, sugar alcohols, myo-inositol, carboxylic acids and inorganic anions in developing grains from different varieties of Robusta (Coffea canephora) and Arabica (C. arabica) coffees. Plant Sci. 149: 115-123.

Rojas-Herrera R, Loyola-Vargas VM (2002) Induction of a class III acidic chitinase in foliar explants of Coffea arabica L. during somatic embryogenesis and wounding. Plant Sci. 163: 705-711.

Sacandé M, Groot SPC, Hoekstra FA, De Castro R, Bino RJ (1997) Cell cycle events in developing neem (Azadirachta indica) seeds: are they related to intermediate storage behaviour? Seed Sci. Res. 7: 161-168. 
Sacandé M (2000) Stress, storage and survival of neem seed. Wageningen University, Netherlands. PhD Thesis.

Schilter B, Cavin C, Tritscher A, Constable A (2001) Health effects and safety considerations. In: Clarke RJ and Vitzthum OG (Eds) Coffee: Recent Developments, pp. 165183. Blackwell Science, Oxford.

Schultze M, Kondorosi A (1996) The role of lipooligosaccharides in root nodule organogenesis and plant cell growth. Curr. Opin. Genet. Devel. 6: 631-638.

Selmar D, Bytof G, Knopp SE (2001) New aspects of coffee processing: The relation between seed germination and coffee quality. Proceedings of the $19^{\text {th }}$ International Scientific Colloquium on Coffee, Trieste, International Scientific Association on Coffee, Paris, CD-ROM-C326.

Shimizu MM, Mazzafera P (2000) A role for trigonelline during imbibition and germination of coffee seeds. Plant Biol. 2: $605-611$

Silva EA (2004) Influência de distintas condições edafoclimaticas e do manejo de irrigação no florecimento, produção e qualidade de bebiba do café (Coffea arabica L.). Campinas University (UNICAMP) SP, Brazil. PhD Thesis.

Silva EA, Mazzafera P, Brunini, O, Sakai E, Arruda FB; Mattoso LHC; Carvalho CRL, Pires RCM (2005) The influence of water management and environmental conditions on the chemical composition and beverage quality of coffee beans. Braz. J. Plant Physiol. 17: 229-238.

Söndahl MR, Baumann TW (2001) Agronomy II: Developmental and cell biology. In: Clarke RJ and Vitzthum OG (Eds) Coffee: Recent Developments, pp.202-223. Blackwell Science, Oxford.

Speer K, Sehat N, Montag A (1993) Fatty acids in coffee. Proceedings of the $15^{\text {th }}$ International Scientific Colloquium on Coffee, Montpellier, International Scientific Association on Coffee, Paris, pp.583-592.

Speer K, Kölling-Speer I (2001) Lipids. In: Clarke RJ and Vitzthum OG (Eds) Coffee: Recent Developments, pp.3349. Blackwell Science, Oxford.

Stiles JI (2001) Molecular biology. In: Clarke RJ and Vitzthum OG (Eds) Coffee: recent developments, pp.224-234. Blackwell Science, Oxford.

Tressl R, Wondrak GT, Garbe LA, Rewicki D, Krüger RP (1998) Pentoses and hexoses as sources of new melanoidin-like Maillard polymers. J. Agric. Food Chem. 46: 17651776.

Uefuji H, Ogita S, Yamagushi Y, Koizumi N, Sano H (2003) Molecular cloning and functional characterization of three distinct $N$-methyltransferases involved in the caffeine biosynthesis pathway in coffee plants. Plant Physiol. 132: 372-380.

Urbaneja G, Ferrer J, Paez G, Arenas L, Colina G (1996) Acid hydrolysis and carbohydrates characterization of coffee pulp. Renewable Energy 9:1041-1044.

Urgert R, Essed N, van der Weg G, Kosmeijer-Scuil TG, Katan MB (1997) Separate effects of the coffee diterpenes cafestol and kahweol on serum lipids and liver aminotransferases. Am. J. Clin. Nutr. 65: 519-524.
Vaast P, Génard M, Dauzat J (2002) Modeling the effects of fruit load, shade and plant water status on coffee berry growth and carbon partitioning at the branch level. Proceedings of the Sixth International Symposium on computer modeling in fruit research and orchard management. Acta Hortic. 584: 57-82.

Vaast P, Angrand J, Franck N, Dauzat J, Génard M (2005) Fruit load and branch ring-barking affect carbon allocation and photosynthesis of leaf and fruit of Coffea arabica in field. Tree Physiol. 25: 753-760.

Vaast P, Bertrand B, Perriot JJ, Guyot B, Génard M (2006) Fruit thinning and shade improve bean characteristics and beverage quality of coffee (Coffea arabica L.) under optimal conditions. J. Sci. Food Agric. 86: 197-204.

Vishveshwara S, Chinnappa CC (1965) Embryological studies in Coffea arabica L. Turrialba 15: 307-316.

Voigt J, Heinrichs H, Voigt G, Bielh B (1994) Cocoa-specific aroma precursor are generated by proteolytic digestion of the vicilin-like globulin of cocoa seeds. Food Chem. 50: $177-184$.

Weber H, Heim U, Golombek S, Borisjuk L, Wobus U (1998) Assimilate uptake and the regulation of seed development. Seed Sci. Res. 8: 331-345.

West MM, Flannigan DT, Lott JNA (1995) Elemental composition of globoids in the persiperm tissue of various seeds. Can. J. Bot. 73: 954-957.

Winston EC, Hoult M, Howitt CJ, Shepherd RK (1992) Ethylene-induced fruit ripening in arabica coffee (Coffea arabica L.). Aust. J. Exp. Agric. 32: 401-408.

Winton AL, Winton KB (1939) Seeds of the madder family Coffee. Structure and Composition of Foods, Vol. IV, John Wiley and Sons Inc., New York, pp.139-162.

Wolfrom ML, Plunkett RA, Laver ML (1961) Carbohydrates of coffee beans. II. Isolation and characterization of a mannan. J. Org. Chem. 26: 4533-4535.

Wolfrom ML, Patin DL (1964) Isolation and characterization of cellulose in the coffee bean. Agric. Food Chem. 12: 376-377.

Wormer TM (1964) The growth of the coffee berry. Ann. Bot. 28: 47-55.

Wormer TM (1966) Shape of bean in Coffea arabica in Kenya. Turrialba 16: 221-236.

Yatsiv S, Flowers HM (1971) Action of $\alpha$-galactosidase on glycoprotein from human B-erythrocytes. Biochem. Biophys. Res. Commun. 45: 514-518.

Yuffá AM, de García EG, Nieto MS (1994) Comparative study of protein electrophoretic patterns during embryogenesis in Coffea arabica cv Catimor. Plant Cell Rep. 13: 197-202.

Zheng XQ, Ashihara H (2004) Distribution, biosynthesis and function of purine and pyridine alkaloids in Coffea arabica seedlings. Plant Sci. 166: 807-813.

Zheng XQ, Nagai C, Ashihara H (2004) Pyridine nucleotide cycle and trigonelline ( $N$-methylnicotinic acid) synthesis in developing leaves and fruits of Coffea arabica. Physiol. Plant. 122: 404-411. 